\title{
The Red Wave Collective: The Process of \\ Creating Art at the Oceania Centre for \\ Arts and Culture
}

Katherine Higgins

\section{The University of the South Pacific}

Minutes away from the bustling streets of Suva, perched above Laucala Bay, resides the University of the South Pacific (USP). The main USP campus, Laucala, brings together students and staff from its twelve member countries and beyond. ${ }^{1}$ Established in 1968, the university's programs meet the needs of the diverse region through a range of academic curricula and courses with distance and flexible learning options. The University of the South Pacific has nurtured important figures in literature, politics, science, and business.

Any weekday morning you can join students and staff headed from Suva to the university. Climb aboard one of the open-sided buses headed out toward Laucala Bay. The experience of the bus is memorable; the combination of seats swathed in shiny vinyl, open air, and distorted music blaring from overhead speakers that cannot handle the decibel level makes for an ephemeral experience. Find a seat among the students and staff and watch the driver's deft negotiation of the roads, weaving the massive vehicle among taxis, dogs, and pedestrians while simultaneously collecting fares and chatting with patrons or on his mobile phone. Soon, the UsP gates and groups of students signal that you have reached your destination; follow suit when the students disembark to join their friends already milling about the campus. 


\section{A Tour of the Oceania Centre for Arts and Culture}

From the university's entrance, walk toward the back of campus, past the classrooms and library, through the groups of students gathered around the cafeteria and dormitories, until you see a structure that does not look like a normal Western building because it has no walls. This sweeping structure sits on a hill; its roofs curve and bend like waves.

Approach the structure to see a collection of strange forms among the scattered bushes and trees. The most prominent is a steel sculpture of a sea creature (see figure 5). More than eight meters in height, this colorful creation hangs like a trophy from a fantastical fishing expedition, not into a "pacific ocean" but into Maui's legendary Ocean. Step onto the path that lies to the left of the monstrous creature and follow the winding cobblestones. You will be greeted by an impressive sentinel, a tall ni-Vanuatu slit gong flanked by trees and skeletal wrought-iron forms of invented animals. Near the end of this pathway, you will come to face a dark, steel fish that curls into itself. Its vertebrae jut out and stand together to represent the USP member countries. This fish, the Oceania Centre logo, peers out and invites you in. Glance back to your left and you will notice a discreet meter-high sign that reads, in small white lettering, "The Oceania Centre for Arts and Culture" (figure I). Around the corner you never know what you will find, but you can be sure that it will be interesting.

This is no art school.

Behind the wall (one of the few in this place) that bears the center's logo, a row of offices begins with an inconspicuous sound studio that generates sounds infused with Oceanic rhythms. A veranda stretches out in a " $v$ " adjacent to the offices-small, enclosed spaces that are filled to capacity with four people, meaning that they are often empty in comparison to the open veranda, which catches the breeze and invites activity. At the end of the colorful mosaic floor separating the veranda and offices, an immense turtle stretches across a wall interrupted by a small doorway. Through the doorway you might turn left into the painting studio, which would probably be an adequate size for one artist but typically accommodates six to a dozen of the Oceania Centre's artists. Opposite the painting studio, at the end of the row of offices, is the welding area. Tools and various scraps of metal are organized between the worktable and a cavity wall that acts as a cement grate, allowing light and air to seep into the small space. This is also a popular thoroughfare as it leads from the offices to the dance and carving areas. 


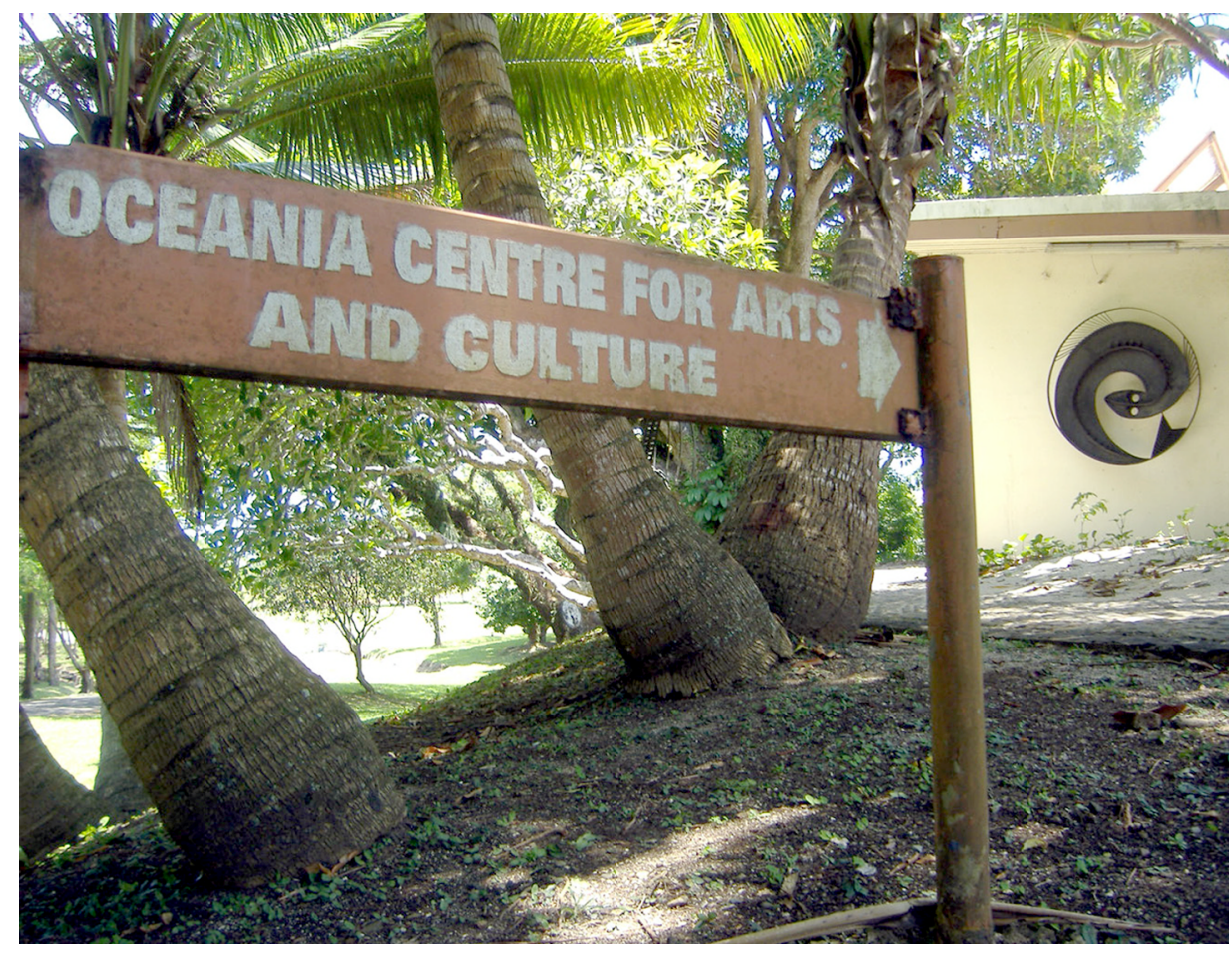

Figure I. Oceania Centre entrance, 2007. Photo by author.

Outside the welding studio, a scattering of makeshift seats borders a steep hill that slopes to the left; to the right is the dance stage. Energy emanates from the raised stage, which extends the length of the building. The dance area is bordered by the offices we have just navigated, while the sculpture area continues in the opposite direction. This side of the Oceania Centre is entirely open, with lofty, arching roofs. The dance area is larger than the office space it flanks; the sculpture area on the other side is the most recent addition and the largest space, where immense sculptures dwarf the craftsmen. If you peer into this space from the street, past the steel sea creature, you will see enormous tree trunks in the process of becoming fantastical animals. You may see bodies soaring through the air, dancers moving in daring physical feats (figure 2). Or you might hear the Niu Waves Writers' Collective exchanging poems during one of their meetings. Since there is no door to knock on, and no walls to enclose the performance of dance or sculpting, curiosity will invite you in, and the smiles of those "working" there will welcome you. 


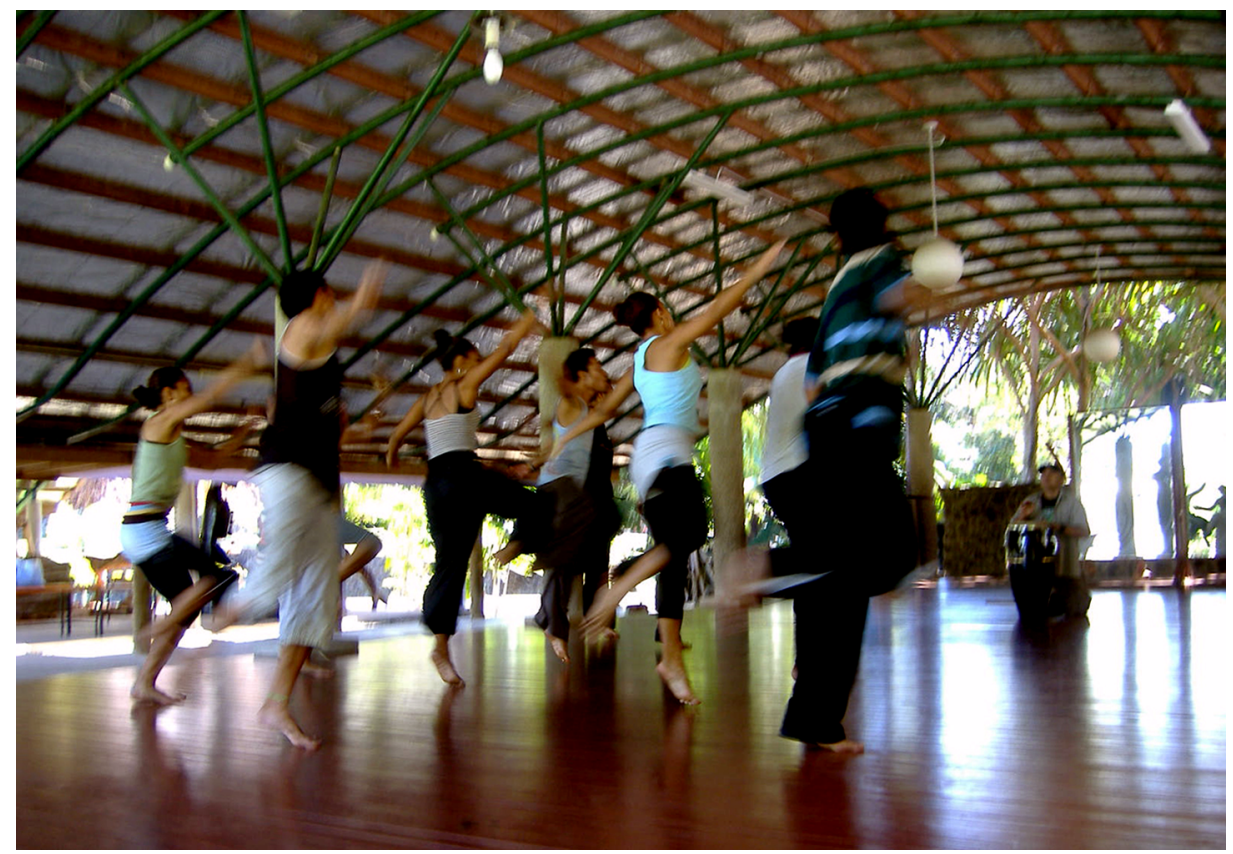

Figure 2. Dance rehearsal, 2006. Photo by author.

\section{Creating Waves}

A creative wave has been gaining momentum for more than decade at the Oceania Centre for Arts and Culture, which has operated as an innovative space to nurture a movement of contemporary art that invites tradition into the present. By describing the space, I intend for you to envision and discover the creativity that thrives at the center. In this essay I focus on the emergence and growth of the visual arts at the Oceania Centre. I also introduce its founder, Epeli Hau'ofa, and some of the artists of the Red Wave Collective. ${ }^{2}$ Although the center encourages and hosts various artistic practices, I focus on tangible arts, such as painting and sculpture. I mention the dance and music programs at the Oceania Centre but do not elaborate on them-scholars with far more expertise and insight have written and will write on these aspects. Nevertheless, I use the term art freely here to imply the combination of tangible art, music, dance, and occasionally oral and written arts, because at the Oceania Centre the artistic practices are inextricable from one another.

The artists at the center represent a burgeoning Oceanic identity infused 
with traditions and histories, which are expressed in the contemporary period through art. What is exceptional is the process encouraged by Hau'ofa, which fosters the potential of each individual while simultaneously forming a dedicated community of artists who learn from one another. The process of creative exchange at the Oceania Centre is integrated throughout its painting, sculpture, dance, and music programs to produce expressions that move like waves with the fortitude and force of the ocean.

\section{BEGINNINGS}

I first learned about the Oceania Center when I viewed a recording of a public presentation given by Epeli Hau'ofa at the East-West Center in Honolulu in 2003. Watching Beyond the Horizon (Hau'ofa 2003a), I was surprised by Professor Hau'ofa's declaration that he had known nothing about art before becoming the director of the Oceania Centre for Arts and Culture. As an anthropologist, fiction writer, professor, and now, for a decade, mentor to young artists, this humble Tongan has long held international recognition. Ten years prior to his 2003 presentation in Honolulu, Hau'ofa provoked colleagues by offering his vision for a renewed Oceania in "Our Sea of Islands" (r993a). He highlighted an Oceania that is an immense, far-reaching "sea of islands," traversed by ancestors who bravely embarked on voyages across vast expanses of ocean using their well-developed navigational skills and guided by a deep understanding of the cosmos. Hau'ofa reminded Oceanians about the accomplishments of their ancestors, which included establishing and maintaining networks throughout the Islands with sophisticated navigation and watercraft technology. He suggested that rather than succumb to prevailing notions of Oceania as small and therefore weak, the people of the region should instead consider the more empowering view of Oceania as strong and brimming with potential (Hau'ofa I993a, 5). "Oceania is vast, Oceania is expanding, Oceania is hospitable and generous, Oceania is humanity rising from the depths of brine and regions of fire deeper still, Oceania is us. We are the sea, we are the ocean" (Hau'ofa I993a, I6).

Professor Hau'ofa's vision for Oceania countered his earlier teaching at the University of the South Pacific, which fell victim to belittling notions and thus did not provide students with much hope. Opportunity for hope and activation of his ideas arose out of a failed attempt to recreate Hawai'i's Polynesian Cultural Center in Suva, Fiji. ${ }^{3}$ In I992, a directive by 
the USP governing council called for the development of a cultural center inspired by the success of the Polynesian Cultural Center, on the island of O'ahu in Hawai'i. A committee was appointed to develop a strategy for Suva's own cultural tourist center but did not make much progress; they "unanimously rejected the idea of . . becoming involved in tourism as entertainers. That was the only thing that [the committee] was united in" (Hau'ofa 2003 b, 4). Unable to establish a viable plan of action, the committee eventually disbanded. A few years later, the idea was revisited and Hau'ofa found himself appointed as head of the committee. Hau'ofa took action and formed a new group on the basis of a specific stipulation: "All those who held contrary views in the previous committee were uninvited" (Hau'ofa 2003 b, 6). Hau'ofa was quietly embarking on what stands today as his realization and confidence in the strength of Oceanians to "cultivat[e] their ever-growing universe in their own ways" (I993a, I 5 ).

Since he was embarking on an uncharted journey into the arts, Hau'ofa invited Georgina and Ulli Beier to write a report and make suggestions based on their successful experiences fostering artists in Papua New Guinea and Nigeria. The Beiers had inspired Hau'ofa when they were all working in Papua New Guinea in the late I960s and early I970s. While in Papua New Guinea, Georgina Beier established art workshops, similar to those she initiated in Nigeria. Georgina went to the laborers to find artists, who often spoke no English and could not read or write. However, with support, encouragement, and perseverance, many of these individuals eventually emerged as internationally renowned artists in their own right (Beier 1974; Hau'ofa 2003a). But while the Beiers' consultancy report for the University of the South Pacific produced ideas and suggestions for a cultural center, ${ }^{4}$ there were still no firm directives when the university established the Oceania Centre for Arts and Culture on I February I997.

Plans for the Oceania Centre had moved through the university's bureaucratic process with unprecedented speed. This speed actually reflected a lack of interest on the part of the powers that be, but the center's marginalization in turn allowed it some freedom. Hau'ofa was appointed director and provided with a program assistant and a part-time cleaner. The Oceania Centre was allocated a building originally built in the I 940 s by the New Zealand Air Force and more recently used to house married USP students; it was a small and functional structure, but not what one would call a creative space. That building is located at the back of the campus, across from the magnificent Fijian bure (thatched house), behind the classrooms and library, and past the cafeteria and dormitories. 
Hau'ofa had a limited budget but plenty of time to imagine something unique: a home for Oceanian arts and culture. Establishing objectives was easy for Hau'ofa because it provided an opportunity for him to activate his earlier ideas for nurturing an Oceanic identity. Along with his own vision, Hau'ofa considered Georgina Beier's art workshops in Papua New Guinea and Nigeria. ${ }^{5}$ He was also inspired by Futa Helu, founder of the 'Atenisi Institute in Tonga, ${ }^{6}$ who had once told him, "All the knowledge in the world we can teach without money" (Hau'ofa 2003a). These influences, combined with marginal funding and attention from the University of the South Pacific, prompted the center to find strength within and to appreciate its independence. The latter influence set the Oceania Centre's cardinal rule of not making insistent demands on the university, especially on its financial resources. Hau'ofa felt that such demands "would attract unwelcome attention to what we were not supposed to be doing" (Hau'ofa 2003 b, 7).

The objectives of the Oceania Centre remain the foundation to all that has developed there. The center strives to create Oceanic images that rely on traditions while incorporating contemporary life, in Hau'ofa's words, "[images] that speak to us, that speak of us in our place and time" (2003a). The space of the center is imbued with a spirit of reciprocity, cooperation, openness, and participation, and within this collaborative environment the standards for creativity are established and applied by and for the participants. This presents an exceptional opportunity for experimentation as, in developing their own canons, artists develop new styles of expression because there are no fixed criteria; instead, there is process. At the center, the artists aspire to create "forms, sounds, and movements people across the region would accept as theirs" (Hau'ofa 2003a). These objectives provide inspiration for the artists to flourish in their own domain as others have in theirs (Hau'ofa 2003a). Through these objectives, contemporary Oceanic arts emerge, reflective of present-day Oceanic life, inspired by the ocean, traditions, and histories.

The center is relevant to contemporary Oceanic life because its participants are from within the community. Like Georgina Beier, Hau'ofa found artists among school dropouts and the unemployed. These became participants in the center's first drawing and painting workshop, led by Niuean artist John Pule. In I998, Hau'ofa invited Pule to hold the workshop to launch the applied arts program. A self-taught artist, John Pule lives and works in Aotearoa/New Zealand. His early works, patterned with designs reminiscent of tapa (bark cloth), caught Hau'ofa's eye. The 
workshop was the first of many that continue to be held at the center as a means of challenging the artists, demonstrating certain techniques (in dance, painting, and paper-making, and so on), and introducing different artists from outside of Fiji. Since the center was never granted the budget to hire a full-time arts teacher, daily interactions among participants and the workshops create a shared learning experience. The lack of funding for arts instructors proved to be a blessing, because the artists recognized the individual and collective creativity already present within the center's participants. Pule's initial influence led some of the artists to replicate his style, but soon participative learning became the norm and the aspiring artists embraced the center's philosophy that creativity comes from within.

The smallness of the building also fueled the sharing of ideas. Working within a narrow budget, Hau'ofa chose an open construction that allowed expansion at a limited cost. The original dormitory structure became offices and a single painting studio, but over time the center gradually absorbed the surrounding land. Choosing the cost of a roof and floor over walls, Hau'ofa incorporated the openness of Oceanic architecture to make both

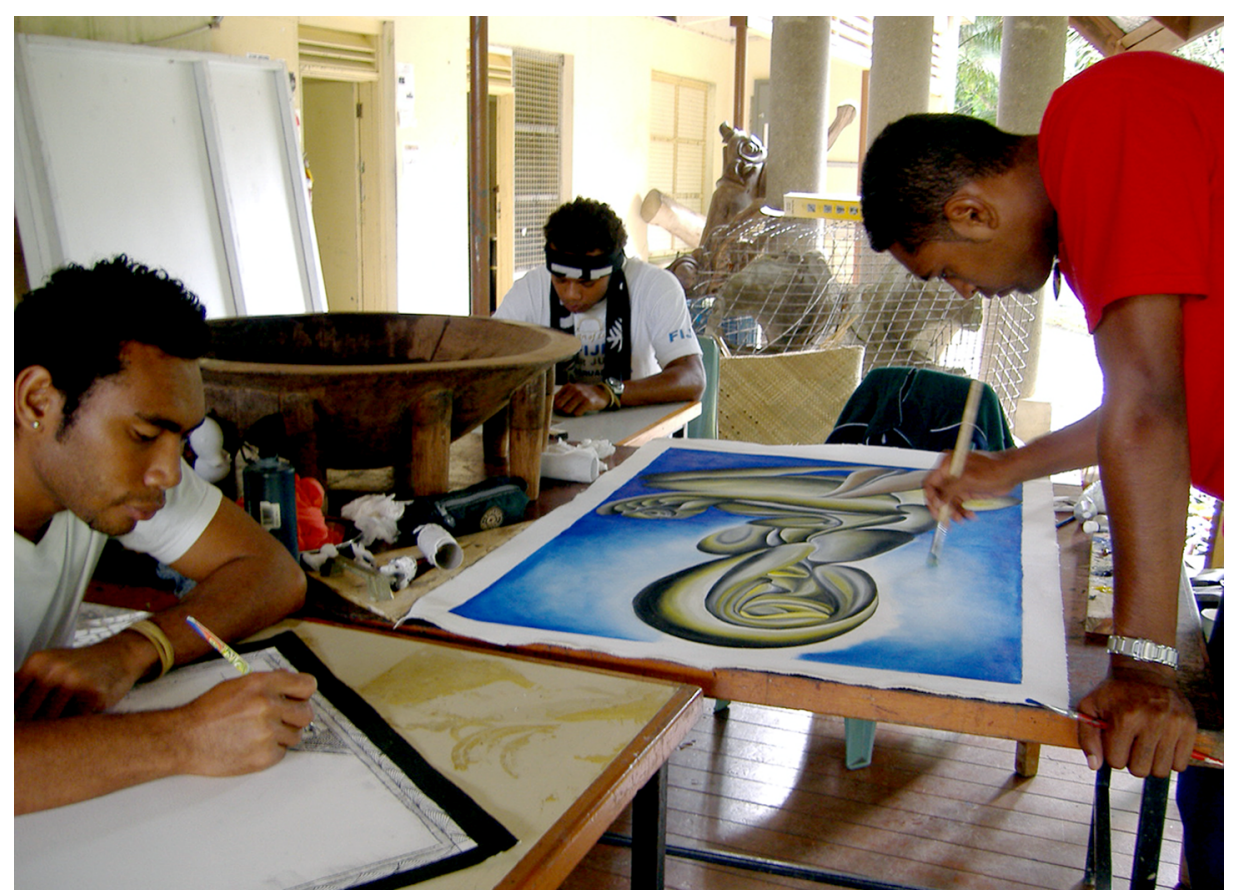

Figure 3. Sekope Tukaha, Irami Buli, and Ledua Peni on the Oceania Centre veranda, 2006. Photo by author. 
the process and product of creation visible (Hau'ofa $2003 \mathrm{~b}, 8) .^{7}$ Although walls and privacy are integral aspects of some Oceanic structures, these open spaces invite communal sharing and learning, and stimulate creativity among the artists. These elements are similar to the openness of a village, creating a familiar and comfortable space that nurtures artists rather than confines them (Epeli Hau'ofa, pers comm, 5 Jan 2007). Further, an open construction attracts an audience of laborers, students, and passersby who feel comfortable venturing in to inspect the Oceanic arts being produced (figures 3 and 4 ).

Over the past decade, the structure of the building and programs has expanded. After the first workshop with Pule, the painters and sculptors formed the Red Wave Collective, a group rooted in the ideals and space of the center while bringing Oceanic imagery to international attention. ${ }^{8}$ The name of the artists' collective, "Red Wave," comes from the Fijian term for a tidal wave, biau kula (literally, red wave), and metaphorically refers to the change in art from traditional artworks to the distinctive contemporary expressions emerging from the Oceania Centre. ${ }^{9}$ While painting

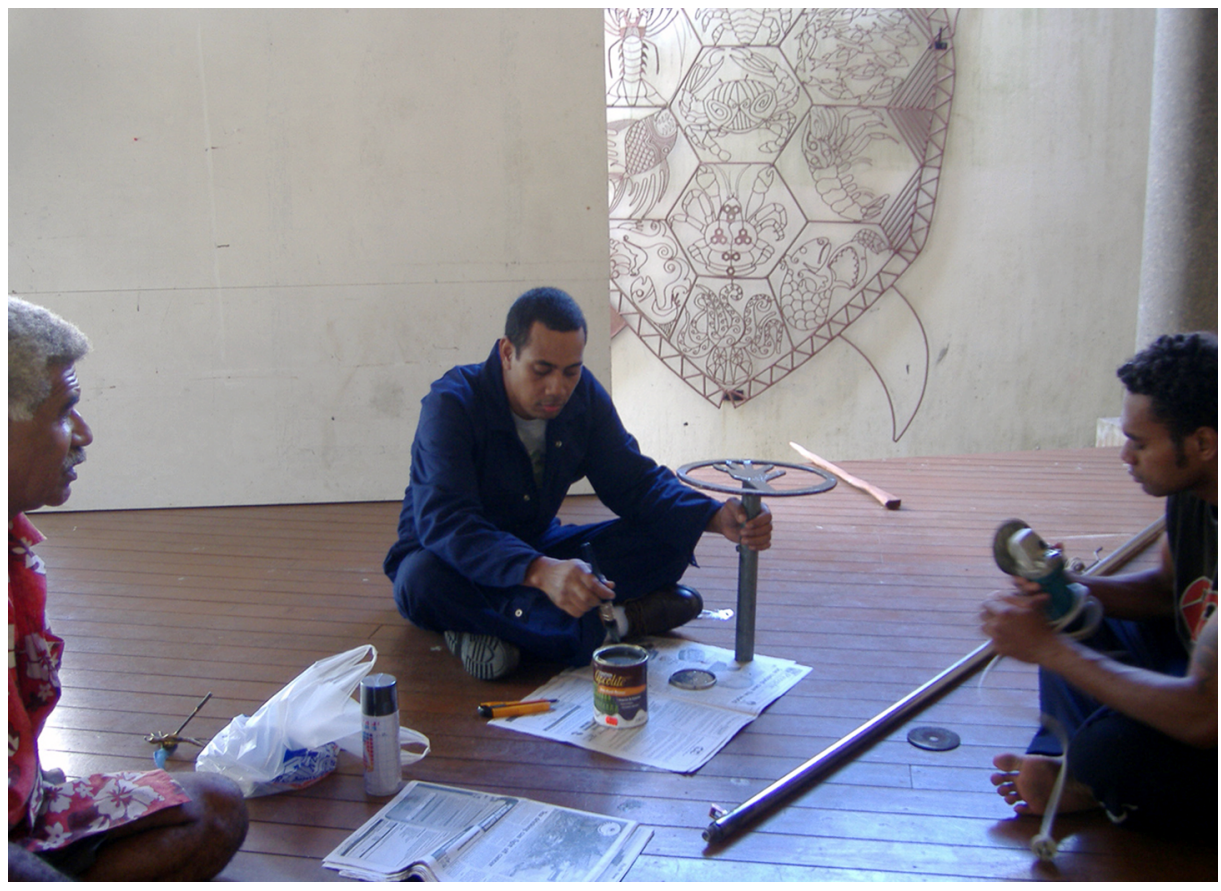

Figure 4. Paula Liga, Ben Fong, and Irami Buli on the Oceania Centre veranda, 2006. Photo by author. 
and sculpture were the initial programs to be set up at the center, interest in dance and music and Hau'ofa's open-door policy fostered the development of a dance program, led by Samoan choreographer Allan Alo, ${ }^{10}$ as well as music composition, production, and performance, led by Fijian composer Sailasa Tora and Solomon Islander composer and sound technician Calvin Rore. The structural growth, which was needed to accommodate the new programs, included an open veranda, dance studio, sound studio, and sculpture area; these open and inviting spaces allow for more dynamic forms of expression rather than confining the flow of creativity within four walls. This unconventional structure invites movement and cross-pollination within the space and programs of the center. The space has become a public space; those who come to visit often stay. The center is full of life, with Hau'ofa preferring to let it speak for itself.

\section{Five Conversations about Art Creativity}

While writing this article, I searched for a method to describe the brilliance of each day I spent at the center. I wanted to present the ideas in an innovative way to honor the creativity thriving there. Then I realized that my own narrative was manipulating the very thing that had inspired me-the artists' stories. So I returned, and, rather than talk, I listened. I listened to what the artists told me. I began each interview the same way: "Tell me about how you came here and about the center." I recognized the artists' excitement by the quickening of their speech, the smiles or laughter that accompanied their words, or the way they leaned in to answer my questions to ensure that I understood correctly. ${ }^{11}$

While my conversations with the artists do not create one thematic dialogue, they highlight a few of the unique individuals painting and sculpting with the Red Wave Collective at the Oceania Centre. The interview excerpts that follow reveal the significance and presence of individual creativity as well as the participative and shared learning that has evolved to nurture creative expression at the center. Each person brings distinctive qualities. Each participant is equal. And each person has potential.

\section{Peni Saimone "Ben" Fong}

In the early quiet of the day, while a peaceful silence hangs over the center, I tap gently on the last door in the row of offices. "Good morning, Ben. May I come in?" 
"Of course Kathie, come in, come in."

I take a seat while scanning the office; I see a combination toolshed and collection closet with shelves of characters constructed out of chains, copper tubing, faucets, and other found metals. The computer that sits on Ben's desk seems out of place in this room.

Ben Fong was one of the first artists to join the Oceania Centre, but as with most artists there, he never imagined this career. An ambitious young man with dreams of being a premier welder, he signed up for a welding workshop. Ben recalls arriving at the workshop conducted by Georgina Beier: "I think we got the shock of our lives. She told us that we were going to make things that God did not intend."

During that workshop, Ben recognized his talent as a sculpture artist, and on completion of the training he brought valuable skills from his welding and engineering background to the Oceania Centre. Ben has been an asset to the center, assisting with design development.

Ben, who created The Way the World Should Be, the sea creature that welcomes visitors at the entrance to the center (figure 5), begins talking about constructing such a massive sculpture before the larger dance and sculpture areas were built. ${ }^{12}$ Grinning, he recalls, "The resources were minimal so I had to do other things. I had to do everything manually. I had to use ropes and such.... You've got to have a bit of an engineering background to figure out things like that, eh?"

He continues, amused by his recollections. "What happened is, in the past we looked more like a refugee camp. Yes, I don't think the university was very happy with us. We had tents all over the place. . . My metal sculpture was made in another tent outside. And since we didn't have a proper workshop, I used a wall" (figure 6).

I ask him to explain the curious sculpture.

Now before I go into that I [should] explain a little bit about myself. I've got the name Fong. ... I am using that as my surname. That is a Chinese name, my mom is Chinese ... [and] my dad, he came from the village [in Lau]. My dad was a sea man, he traveled the world. ... It is assumed that I am Chinese; I am not, ${ }^{13}$ but I was raised around my mom's family. . . For me, being raised with my mom's family, I saw how Chinese people live their lives and I saw the things that matter to them the most. [But] I still attend my dad's tribal meetings and all sorts of things, and I see how my dad's family lives their life. I think that I am fortunate to have the best of both worlds.... Some of my being raised in these two worlds has to do with some of my work. One of those is the sculp- 


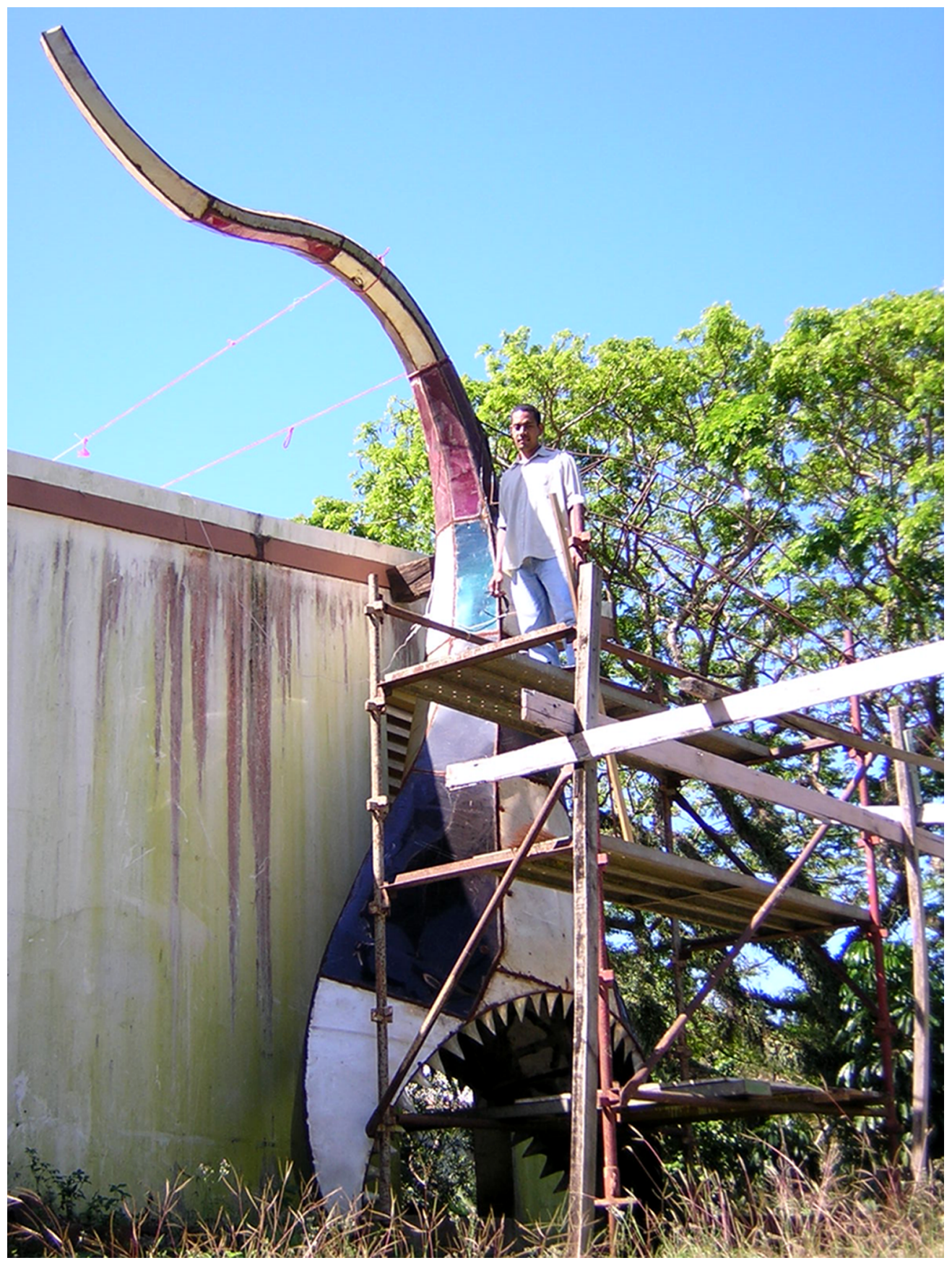

Figure 5. Ben Fong working on The Way the World Should Be, 2004. Photo courtesy of the Oceania Centre for Arts and Culture. 


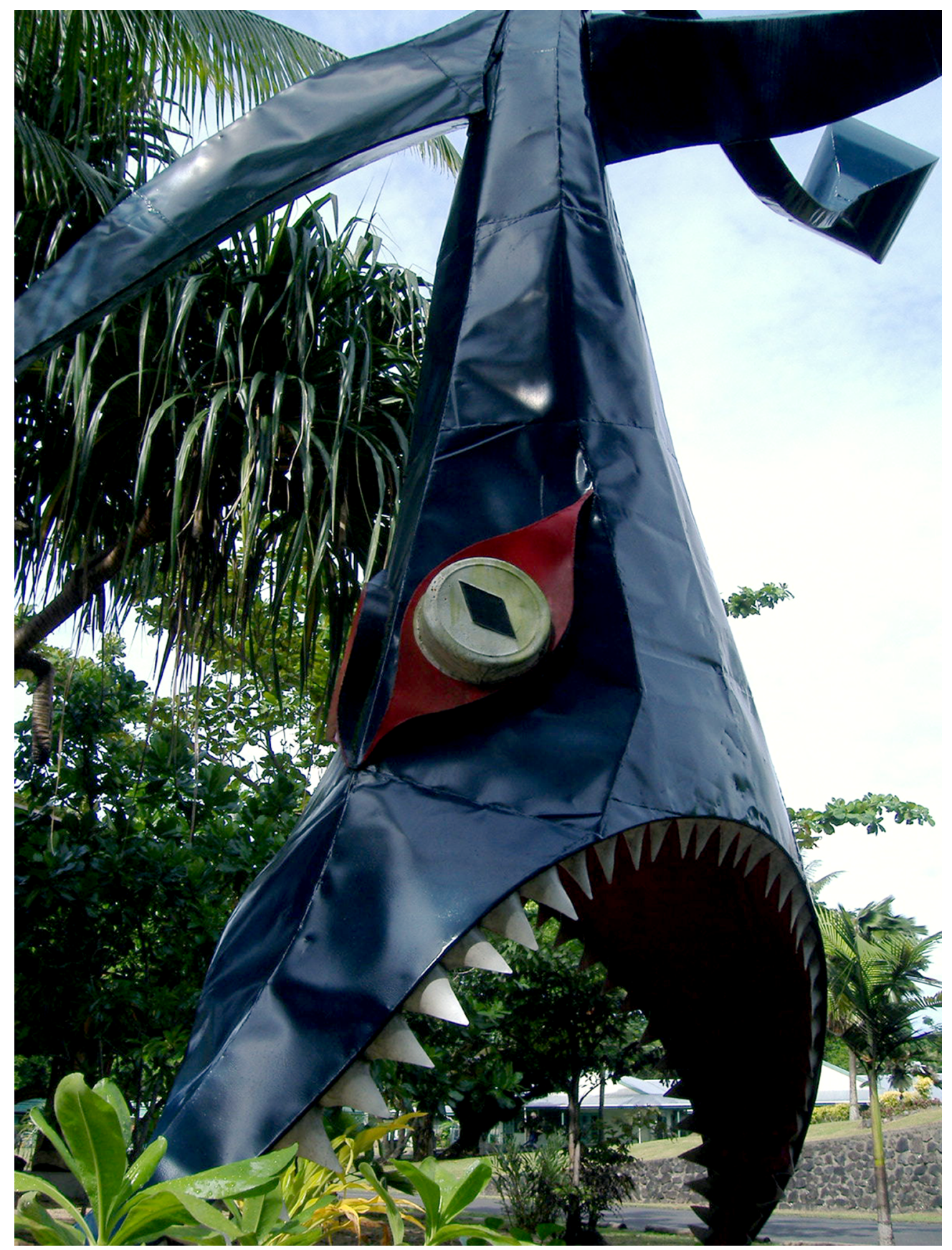

Figure 6. The Way the World Should Be, by Ben Fong. Steel and iron, 2004, 8 m. Photo by author. 
ture outside [The Way the World Should Be]. That one, I was inspired for that one by the political upheavals that happened in Fiji. . . . I just really don't think that I, as an indigenous Fijian, want someone like George Speight representing my people. I don't want him representing my people. He knows nothing about my people. He is a very well educated person. But still, I would prefer if there was anything to be done for the Fijian people, I would prefer that it was done legally, and it followed the due process of the law. ... George Speight did not fight for me, and he has not fought for me. Now he's [brought] in race, he has played the race card, he said that he is doing it for the Fijian people. Well, for me, he's never done it for me. If you see my sculpture, at the top-I've split it into two-there's the top half, which has an arm that is extending toward the front and there is an arm that he is standing on, the mouth of the fish is on the ground, he is also standing on it. Now if you look at the eyes of the sculpture, one is sunk in and one is popping out. I saw that like George, that some of our chiefs, some of our politicians influencing people in society, I saw them as having an eye out for an opportunity; whether it was legal or illegal, they'd take it. And the teeth of the sculpture, I did that because I thought that when opportunity presents itself, be it legal or otherwise, these sort of people seize their opportunity and if anyone was to stand in their way they would chew that person up or would chew that group up and spit them out as if it was nothing, as long as their ends were met, as long as their agenda was met. That's the way I saw it. And also the bottom half of the sculpture also shows a bit of Fiji that is not shown in tourism brochures; it is not shown in ads, it is not shown overseas: the poverty, the discrimination, the fighting for indigenous rights. I think we indigenous people have our rights. I think there are other elements who are exploiting these rights, and I wouldn't want anyone exploiting indigenous rights, but at the same time I would not want my people, indigenous people, asserting themselves illegally on other people for that matter; that is the bit that the bottom half of the sculpture shows. There are a lot of poor people, there is a lot of oppression, there are a lot of these things that's not shown. The top half of the sculpture, it shows Fiji the way the world should be: tall swaying coconut palms, long white sandy beaches, crystal clear blue waters. It shows paradise. It shows all the lovely things of Fiji. But beneath all that there is a whole lot of rumbling happening underneath and a lot of people are not willing to [acknowledge] it, I think it is being suppressed, and I for one am not going to have these things suppressed. Because I don't want my children growing up in a bad Fiji. . . . Despite them being indigenous Fijians, despite them having their roots well maintained, having their indigenous connections, despite all that, I would not want them supporting any upheaval. I would not want that. I would want them living in peace with everyone else. There is a lot of nastiness in Fiji, there is a lot of greed but it is all being hidden. . . That is basically what that sculpture means. 
This sculpture remains a constant reminder of the discontent, frustration, and anger of the Fijian people. In times of political unrest in Fiji, some create riotous stirs via media outlets. Ben's commentary does not require media coverage; instead, his response to the political tensions in Fiji is expressed through the compelling language of art.

I am curious about the audience for this kind of politically charged and deeply personal expression. In an even, matter-of-fact tone, watching me with attentive eyes to ensure that I understand the fundamental meaning of his work, Ben explains: "I don't think I create for an audience. . . . I think I create for myself. I create what I want to. I create certain things that inspire me. I don't create to make people happy. ... If I were to create to make people happy, to me, it would be meaningless because I wouldn't be doing it for me. . . . For an audience, no. But I have done numerous sculptures [that] have been appreciated by other people [see, eg, figure 7]. [They've] been taken overseas, I've won national awards for them, but creating for other people, no, I am creating for me and my family."

Getting up to leave, I ask one last question. "Would all of this be possible without the Oceania Centre?"

Again, the grin: "It's impossible. I don't come from a wealthy background. I don't come from a background where I am able to put together equipment. I have the know-how but ... without the Oceania Centre, Ben the artist would not be here."

With the finality of his statement, I take my cue and depart.

\section{Josua Toganivalu}

Josua Toganivalu has been a member of the Red Wave Collective since its inception in 1998. Although he has come and gone from the center because of his career as a graphic designer and teacher at Fiji Institute of Technology, he remains connected to the center. We walked around the USP campus one afternoon and he showed me his first painting, which was purchased by the university, as well as several others that have been installed around the campus.

$[\mathrm{My}]$ inspiration ... [is] from my cultural background and my family ... inspiration from the artworks that I saw on masi and tapa [bark cloth] and just getting inspiration from artists like John [Pule]. John was there just to guide us and for us to create our own style and identity. ... [As] with my [stories and visual] style of painting, I tend to use the earth colors that are seen ... on those bark cloths, then instead of using the masi and tapa, I [use] canvas [eg, figure 8]... [ [I] include my own stories ... legends and some of my personal 


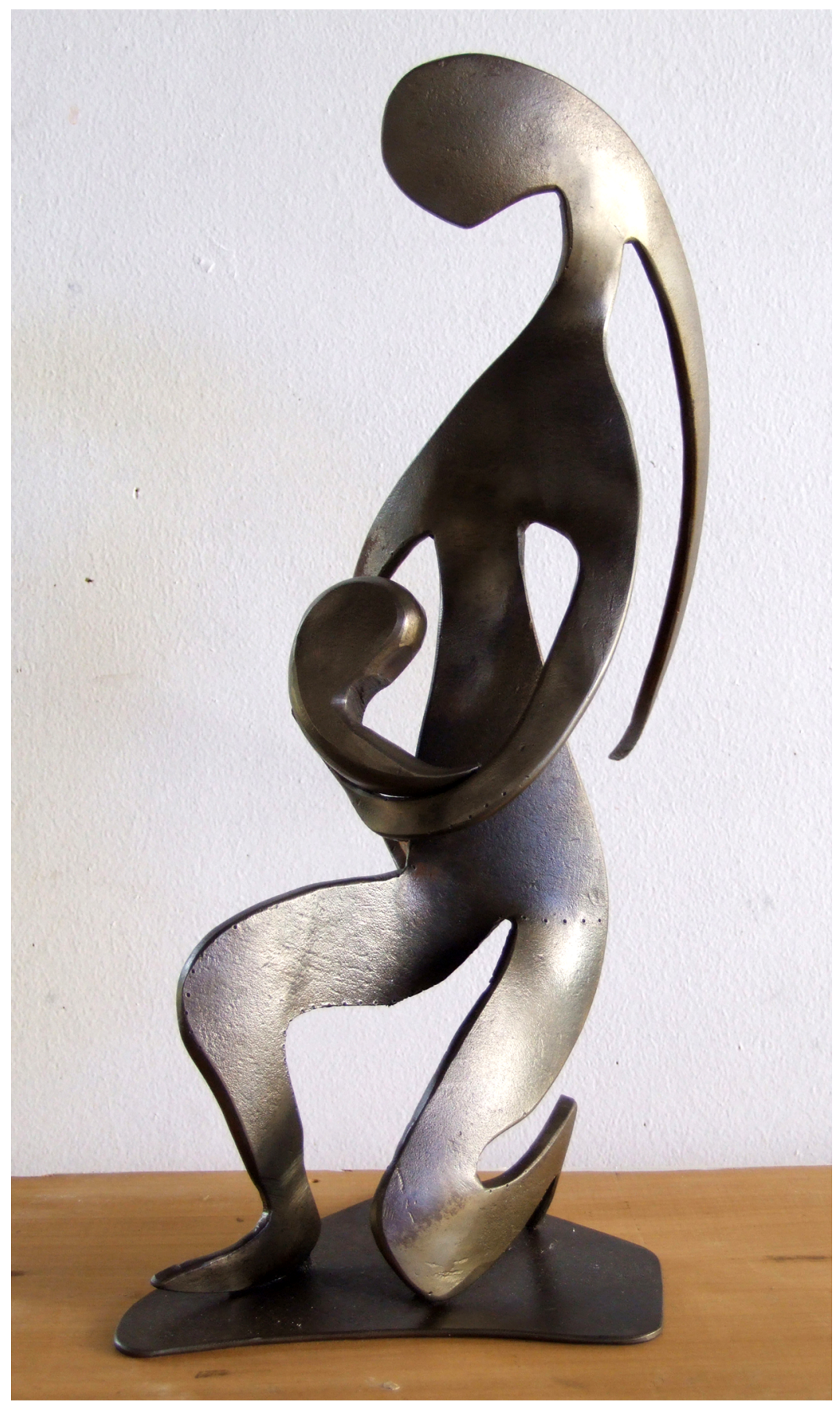

Figure 7. Mother and Child, by Ben Fong. Steel, 2006, 4I cm. Photo by author. 


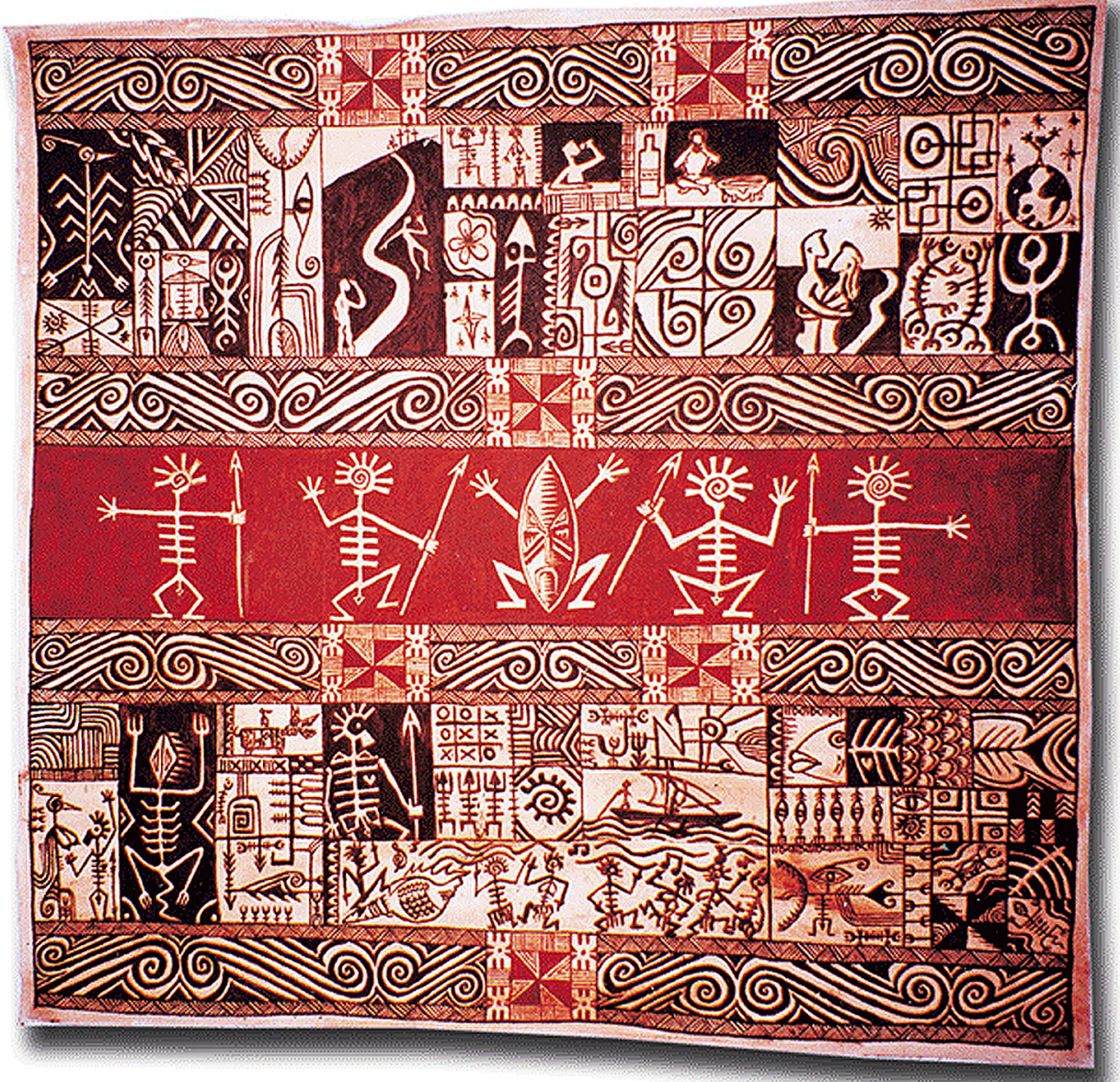

Figure 8. Speardance, by Josua Toganivalu. Oil on canvas, I998, I m X I m. Photo courtesy of the artist.

issues ... the journey of life. . . . With my work, I put images that people can see and relate to. And they can see they're on the same journey that I am on.... My place on [portraying this journey] is ... I don't see it as [just] ... introducing contemporary and mixing it with the traditional. I see it as a way of combining the two cultures, the modern and the old images, using my own style of painting and design, and I see it as a way of mixing the old tradition and my new tradition [figure 9].

I ask Josua about the changes he has witnessed at the center.

My experience, looking at the center today, I can say that the center has really grown and developed in regards to the size, the structure of the center, the 
number of artists, and the arts going on at the center. We've got the visual artists with the paintings and then we've got the music, contemporary dance with Allan [Alo], and wood carving. . . . From the first day that I came here to today, I [can] say that there has been a really huge development . . . and it's good to see the arts and the artists here being recognized. ${ }^{14}$.. I am looking forward to seeing this place grow and having its own art gallery ... and the development of arts and the artists.

For me, my personal connection with the center is very . . . intimate. . . . Because of that passion that I have for arts and painting, my connection with the center is something . . that I hold personally . . . the center is like a part of me. Being part of the center [is] also a source of inspiration. And just being here ... sharing ideas and learning from other artists and respecting other artists' work and just mingling here, you get that creative energy flowing . . . and so it ... inspires me.

I ask Josua about the learning program at the Oceania Centre from his perspective as a graphic design lecturer at Fiji Institute of Technology.

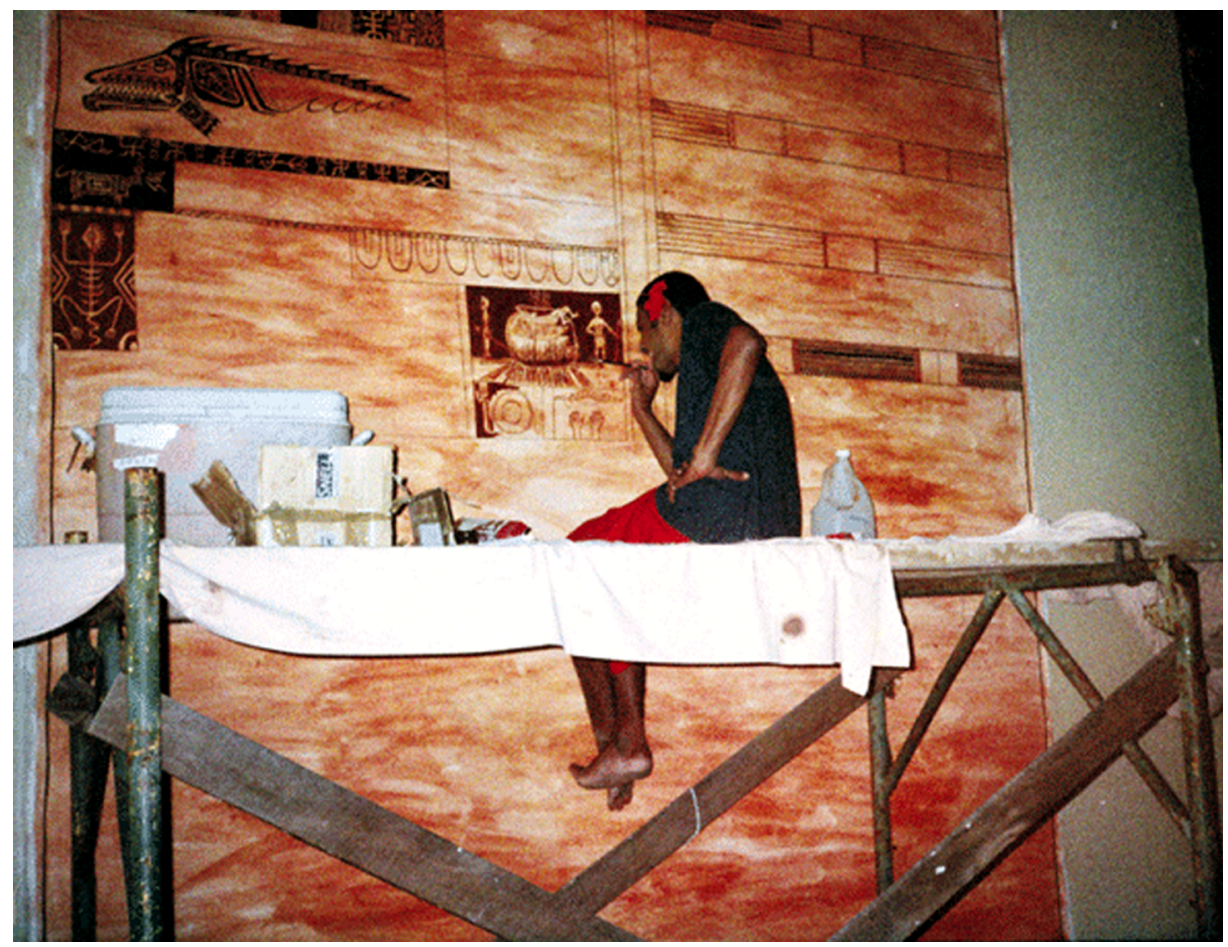

FIgure 9. Josua Toganivalu working on Beautiful Wild Sabooki, wall mural, $4.5 \mathrm{~m} \times 3 \mathrm{~m}$, I998. Photo courtesy of the artist. 
There are not academics here [and] I have no problem with that because with painting it's about the individual creativity, what's inside an artist. So those types of creativity that [are] in an artist, you will not get in school. ... There are a lot of creative people around and ... they don't have the opportunity to go and get the funding to go and get a higher education in arts. They just have it in them and with this place ... offering painting workshops, it's okay for there not to be any academics because the artist's creativity comes from within the artist himself.

\section{Josaia McNamara}

Josaia's recent painting area is at the back of the office structure, hidden behind wooden screens that otherwise function as the center's gallery (figure Iо). Josaia uses the alley behind the multifunctional walls as his own space, although he is never alone, as he is only steps away from the dance stage. He invited me to view a painting he had just finished.

Josaia had been practicing contemporary art before he came to the Oceania Centre's workshop in 1998. In his village he was painting on masi. I recognize the patterns and organization of masi designs, but there is a cosmic quality to his painting, as celestial forms float over idealized masks and decorated faces. Josaia's paintings express his experience as an artist in the village and the city, in traditional and contemporary times, fusing binaries in beautiful imagery. These qualities are apparent in The Sacred Foundation (figure II).

The afternoon sunlight spills underneath the roof, and lights up Josaia's already luminous painting. I ask him about his style. He replies:

I see myself as a visionary artist. ... My works are very influential for me. My three basic principles in life, which I strongly believe in, [especially in terms of] my growing periods, [are] ... my Fijian cultural background ... my religious [beliefs] as a Christian [and] also my own ... personal spirituality. ... These three basic principles [are] actually being formulated through me and in my works. It is a testament ... [and these are] my foundation stones. ... My inspiration was long before this place. It is only here that we establish ourselves; this is the place that I actually established myself professionally. . . I I think inspiration doesn't only exist in this place.... Here, we are pioneering into something greater than what [has] already been founded at this time [in terms of Oceanic arts]... I see that this place is [going to] become an institution.... [But] being here [now, at this level, we are really being creative, a creative force.

We have been working collectively and also collaborating with other artists.... The Red Wave artists ... want to bring in the creative artists, people from outside [and] throughout the Pacific to be part of this movement. So we 


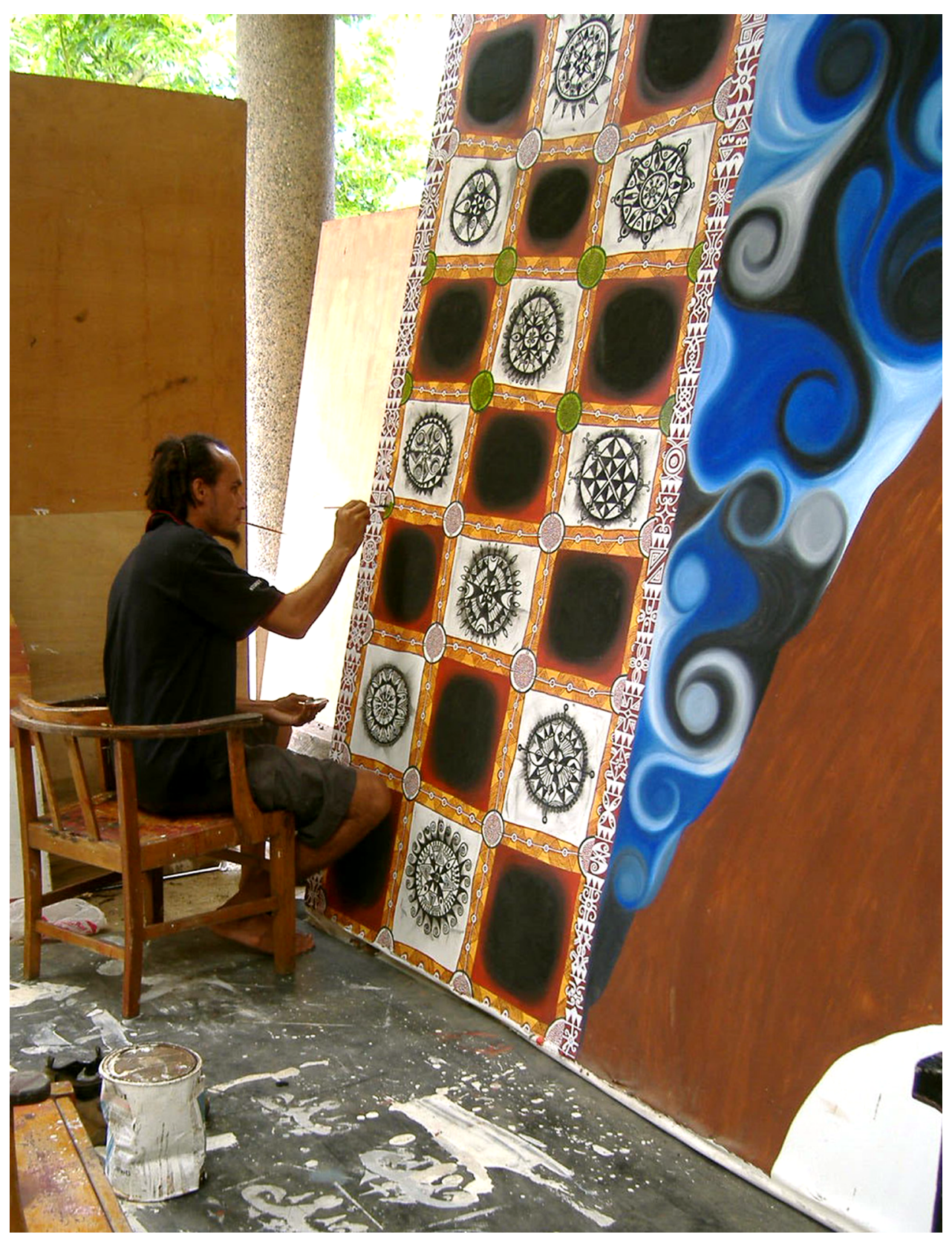

Figure io. Josaia McNamara near the Oceania Centre dance stage, 2007. Photo by author. 


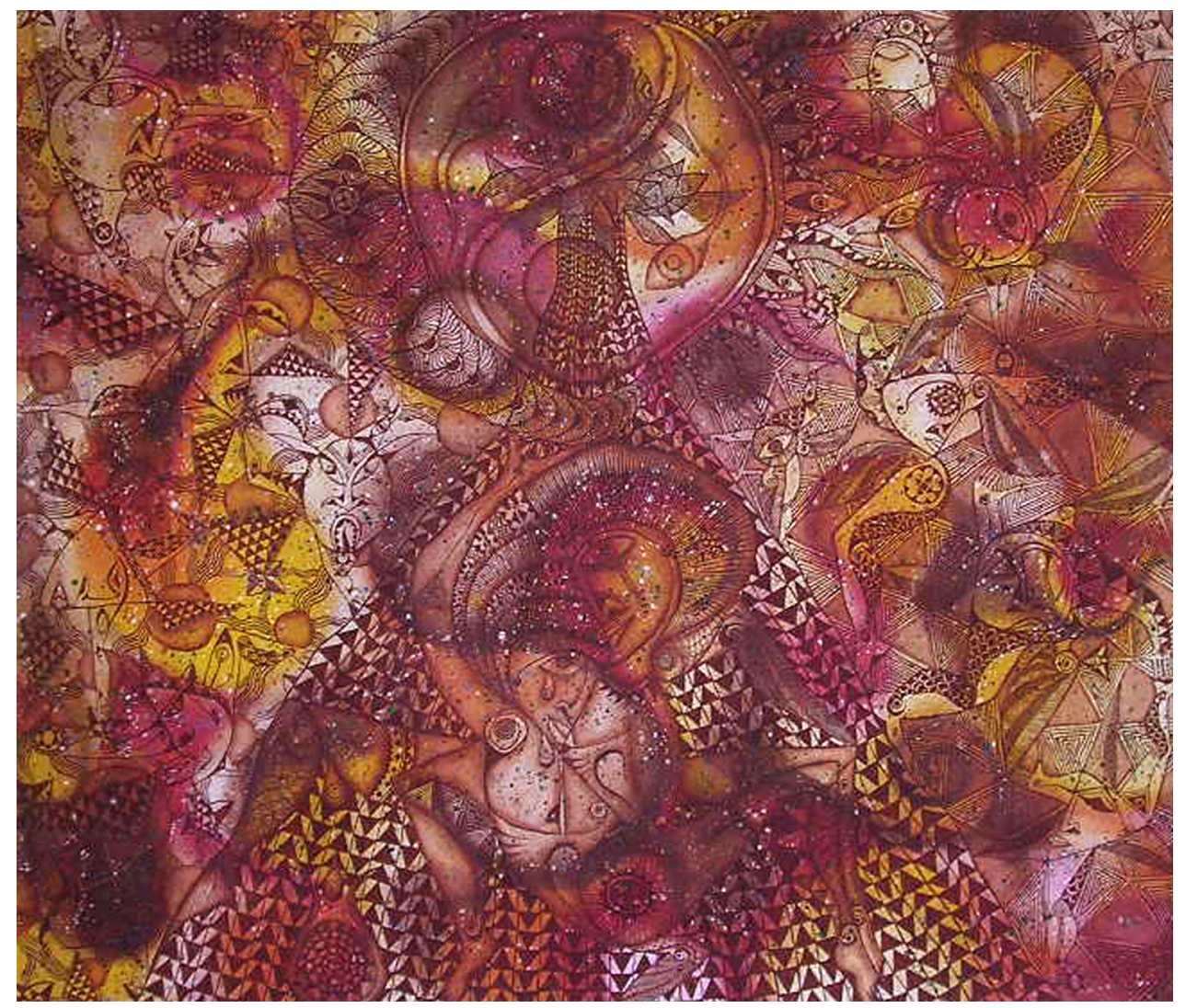

Figure i I. The Sacred Foundation. Josaia McNamara, oil on canvas, 2006, $200 \mathrm{~cm} \times 200 \mathrm{~cm}$. Photo courtesy of the Oceania Centre for Arts and Culture.

[can] have a strong foundation to bring out our voice to this region and . . . to be strong.

Josaia's current paintings are philosophical representations of religious ideals. His work can be enjoyed for the essence of color or the veracity with which he replicates ancient alphabets that he has researched at the University of the South Pacific. Although he always begins with Fiji, his culture, and his roots, his final expressions become universal. Josaia is another example of the freedom and innovation at the Oceania Centre. But his art may have never reached this stage nor provoked so much contemplation if it were not for the program at the center, which is conducive to his process of creation and inspires him as well. 


\section{Irami Bulimaivale Uluinasaravi}

Irami Buli keeps me guessing. Many of our conversations led to discussions about style and other artists whose work we enjoy; his influences are vast and varied. Irami reads whatever he gets his hands on and enjoys writing about his own ideas of art and philosophy, among other things. I am constantly making an effort to decipher Irami, his painting styles and motivations. I find myself contentedly accepting the fact that I will never know Irami's work because it is always in a process of becoming. He is constantly challenging himself and experimenting (figure I 2).

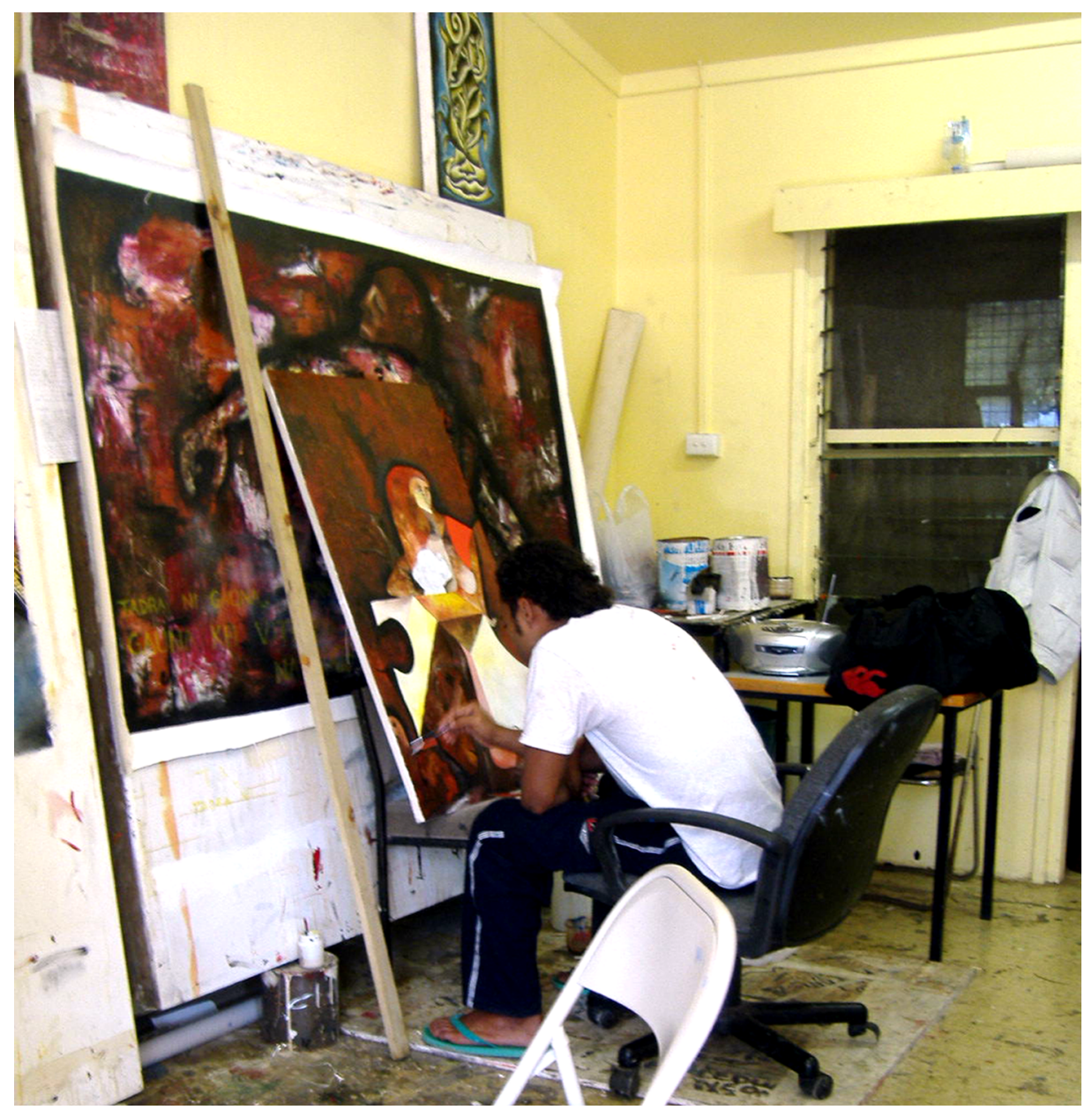

Figure I 2. Irami Buli in the Oceania Centre painting studio, 2006.

Photo by author. 
Irami begins by telling me about how he drew comics as a child, which is why he decided to try out the workshop in 2000 and picked up a paintbrush for the first time. I ask him about his time at the center and how he came to develop the various styles he currently practices. "Well, the technical skills [and] the idea [are relative to] how your mind can go, how your mind can reach the stars or go down deep into the sea. . . . I've painted things that I have found and not what I have seen [eg, figure I3]. It is an amazing experience for me, as an artist. ... I have been here ... the whole of my life. It's ... inside [me], I can't live without it."

Like some of the other artists at the center, Irami paints, dances, and plays instruments. Having seen him participate in all of these in the span of a single day, I ask him about this rigorous practice. Irami tells me:

For me, art is generalist ... art is not only painting. The reason why I feature painting, painting into dancing, and dancing into music, and reading . . . is because it gives me more knowledge, not only about painting, but to physically train [myself] is a form of art. ... [You can] create a painting [in your mind, then] you can come to music and come to [achieve] more knowledge in music, you can create something else in music. [You can] create something else in dance. [All these aspects] give you a more creative mind in this space.... This

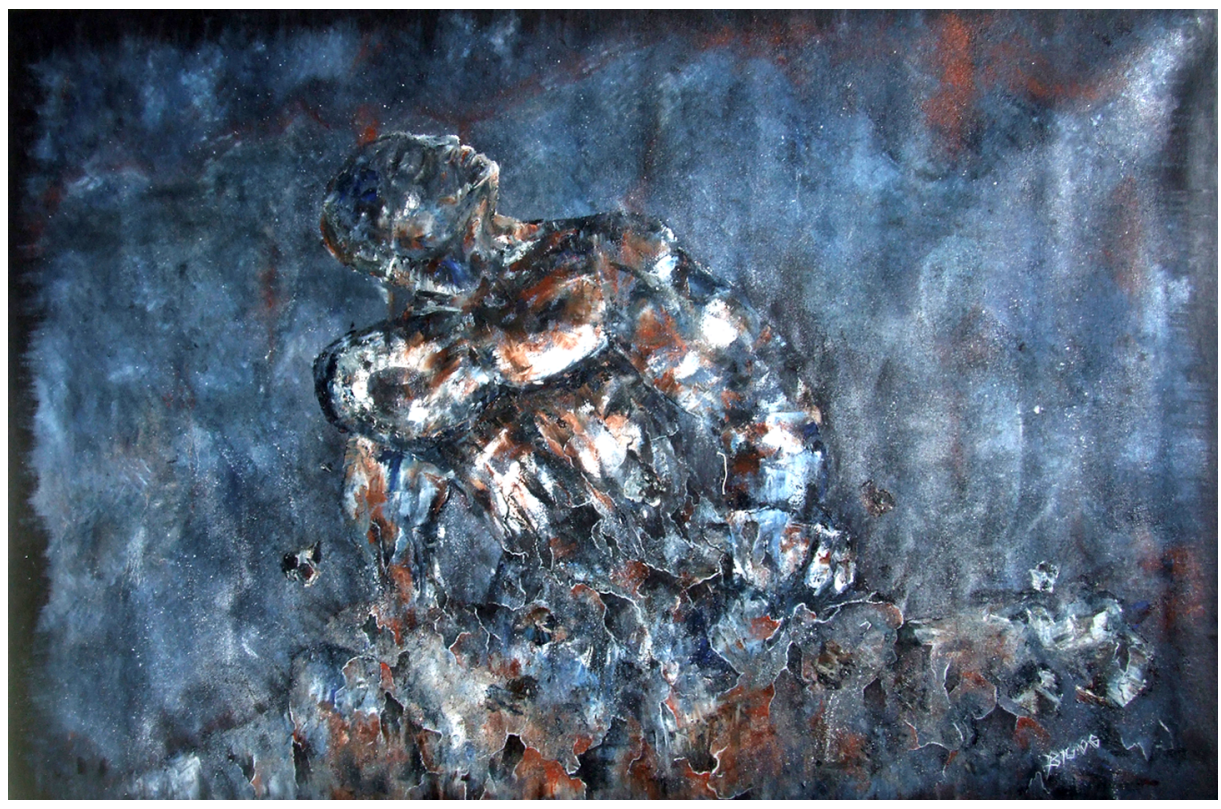

Figure i 3. The Emerge of My Being. Irami Buli, oil on canvas, 2006, I $\mathrm{m} \times 2 \mathrm{~m}$. Photo courtesy of the Oceania Centre for Arts and Culture. 
is much more, although it is not a proper gallery, it [has] more freedom for an exhibition.... I prefer that things are open ... to have four walls is to be in a box. This is sort of like a wave.

The movement of the space encourages the process of experimentation and learning that continues on from the workshops. Irami tells me about the workshops:

It's not really teaching; they do a demonstration of new art, new media . . . [to] collaborate [and] work from that ... to use [those] skills to start something else. ... It is amazing and it gives you more ideas. [Although we are] working in a small space ... I think the mind is very powerful. We all have different minds. . . My mind is concentrating on what is really happening right now, [to] sort of change the view, change it, [and] change the concept of what I see. And [as] some minds [go] right down deep into the sea, some go back into the past. That is the way we can find our own identity, rather than some of the other places [where artists] stay together and copy one another's styles.

"So this is where your artworks come from?" I ask.

My work is often based on a new angle, [the] way I see the world. [I] sort of take an idea and change it. . . It was really hard for me, the first time, to find myself, my own identity. But it came to a point where I found a new direction. I found new ways, I did follow this road and it took me somewhere else.... And art, to me, I believe it's from the mind. It's from the inside of you and that's beautiful. You don't have to go and learn about art and get a masters and a $\mathrm{PhD}$ in art [to] say you're an artist. I don't believe that. An artist is someone who creates something from their own mind and transfers it to a canvas.

\section{Lingikoni Vaka'uta}

I join Lingikoni (whose art is featured throughout this issue of The Contemporary Pacific) in the gully that separates the center from the campus housing for families. We find occasional shade in the shape of the tree swaying overhead, with music wafting across from the dance stage, and a breeze occasionally sweeping his words down toward the playing field below. I listen as Lingikoni tells me about himself, his inspiration, and the process of creating at the center. Originally from Tonga, Lingikoni has been living in Fiji for twelve years. Like Ben and Josua, he has been at the Oceania Centre since the beginning.

At that time [I997,] I was schooling and . . . just lost [interest]. I didn't want to go back to academic work or schooling .... and then I found this workshop 
that was advertised ... and then I . . f found something in me that I always wanted to do. ... It's a hard life. ... Y You have to really make a conscious decision to be an artist in the Pacific, in the Islands, because the money doesn't really come in constantly. But I guess it depends on your passion, if you really want to do it, because for a lot of people it comes from [the heart].

I work with Tongan legends, ancient legends. I use a lot of the Tongan metaphors... [that have] two or three meanings in one sentence depending on how you use it. I use that so a piece of artwork can ... have a different name with different images [and] it can actually mean something else. But I also like to leave my artwork to people's own interpretation so ... I use a lot of these... metaphors. . . . I don't want to copy the whole traditional Tongan designs because it would just end up duplicating what our ancestors have done. So what I do is somehow create my own. And I may borrow a little bit but I just cut it up and twist it around.... I guess that is what contemporary art is.

We sort of improvise; we have been improvising for a long [time]. ... We improvise a lot [at the center]; we paint where there is available space.... [For us] as artists, improvisation is a good thing. ... We [improvise and] encourage the younger artists to find a space and just paint. If what is driving you is your passion for art [then] you can survive ...

[At the Oceania Centre,] we borrow the Pacific concept. If you grew up in the villages ... you watch the older people do stuff. ... Sometimes they tell you what to do but most of the time you just watch and you do it. ... It's the same thing here; now we just bring in the new artists ... we have the workshops... and then we just give them the canvas [and say,] "Here is your canvas; you have stories." ... [We] just let them . . . explore. If they want colors, we help them with technical stuff like colors, how to preserve your work. . . . Technical stuff we can help [with,] but the creative stuff ... [we] let the artists create their own [ideas], that way it comes from inside and that way they feel close[r] to their artwork. If you tell them, this is how you should paint, this is what you are going to paint, well, then they're not artists, they're just people who do what you're doing. ... But at the same time ... we want to do our own contemporary thing. ... We have a little bit of Pacific but we don't encourage painting a sunset with coconuts and a thatch house. That is not Pacific art; that is realistic painting using a Pacific scenery.... [We paint] stories ... like a piece of tapa. But it's not tapa, it's a story of figures ...

To run a creative center like this you have to have the space, and you also have to be able to be more lenient and [you can't] run it like a business because, [if you do,] it's going to turn out like a factory for producing artwork for tourists.... I guess in order for a person to run a place like this [he] has to be creative. As a leader he has to look at stories from different angles and he has to address the problem in order to know there are different ways.... [Because this is] creative art for a new wave of movement, you have to be creative and 
[not] just create for tourists. ... You have to create it for art's sake as an artist. Because if you are just going to try to [make] it for selling, we might as well all go to town and sit [at the] flea market ... and sell it for \$20 and \$ Io a piece. But then, at the end of the day what are we?

For me, I want to be an artist. I want to travel. I want to share my culture with lots of people in the world. . . . Here in this space ... [we] need the physical space, but the artists also just need their space . . . the space between artists. Everybody needs that space as well, you and me; as artists, sometimes we need to talk and sometimes we don't need to talk; we also need that space, the infrastructure of space and the space between artists.

Lingikoni tells me about how the space integrates all of the artists, not only the painters but also the dancers, musicians, and sculptors.

A good example is Allan's productions. [For] dance productions we all sit down and come up with a plan. ... [We] contribute and talk with Calvin and Sailasa and they come up with the music.... I come up with the background artworks and the art that they use in different scenes. Then we sit down and the sculpture gang comes ... [and] makes some of the props. . . . Everybody's together in that we have to talk to each other. ... [In] the last production we did a massive backdrop. ... [It] was a big piece of cloth that [ran from one end of the stage to the other] . . . and we painted it in one week. Everybody is working, everybody paints with a brush. ... It's fun and everybody is talking. ... [We] do the backdrop and we also help out in the backstage . . . moving around stuff. ... [Then,] when we have an exhibition, the dancers come and do the drinks and walk around; we help each other.

Everyone at the center understands this integration. Creativity is not limited here. The communal approach to creativity is rooted in the Oceanic value of reciprocity. An artist is never just a painter. Dancers are comfortable with paintbrushes and musicians will choreograph. It is a shared experience and a process of creating contemporary Oceanic arts (figure I4).

\section{This Change in ArT}

My conversations with the artists are sincere and insightful reflections on the day-to-day life of the Oceania Centre. I use them here to offer a glimpse into the space and programs where a unique Oceanic identity is generated through art. These conversations reveal Epeli Hau'ofa's wisdom to invite and nurture a mixed-and-matched group of people who have become innovative artists. I have recorded only a fraction of those 


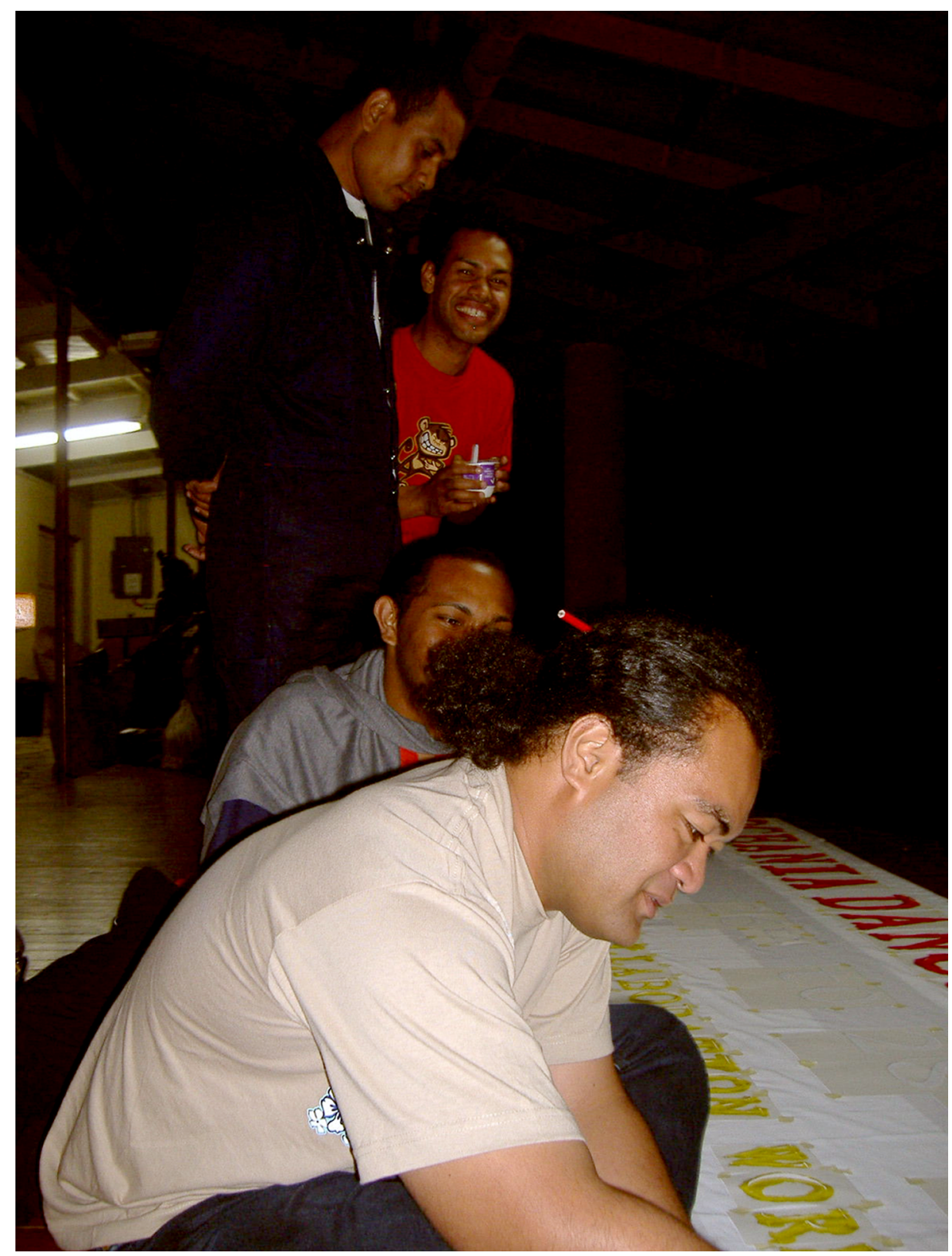

Figure I4. Tulevu Soronakadavu, Ben Fong, Jesoni Naga, and Lingikoni Vaka'uta on the veranda, 2006. Photo by author. 
who, over the past decade, have been forging their own styles based on an Oceanic identity. Some visit for a short while, some stay indefinitely, all contribute, all learn.

What is unique about the Oceania Centre is the process of creation in which artists are forming and quietly yet resiliently asserting their identity. This identity is respectful of and concerned with traditions, histories, current conditions (cultural, social, and political), and overall experience. Vilsoni Hereniko has articulated this point: "Our cultural identities are therefore always in a state of becoming, a journey in which we never arrive" (I999, I38).

Valuing the journey of discovery, the center celebrates the identities of the artists. From the outset, the experience they arrive with is valid and applicable. It is through the process of participative and shared learning that techniques are developed with which they communicate their ideas, empowering themselves and other artists. Mason Lee, another artist at the center, explained it this way: "[When I first came, Professor Hau'ofa] just told [me], 'Get a board and start.' Instead of telling me, 'Where's your sketch?' [or] asking 'What did you sketch?'” In other words, rather than beginning with what is lacking, such as deficiency in technical skill or art theory, participants are welcomed from a positive vantage point that recognizes each person has something valuable to contribute. Their experience is the starting point from which they draw inspiration. ${ }^{15}$ This method of validating the participants from the beginning is unlike the evaluation required for acceptance into many higher educational institutions. Within educational institutions students are often reminded of what they need to learn, often putting aside cultural knowledge and experience to privilege Western models of education. This is evident in Lingikoni Vaka'uta's experience, revealing that the university is not the appropriate model or method for every person. The Oceania Centre provides an alternative for those who choose to look within themselves to produce creative expressions that reflect their experience of the world around them. ${ }^{16}$

Within this valued experience is cultural heritage. The center respects the knowledge acquired in the villages and passed through families, further enacting Hau'ofa's early realizations of an empowered Oceania: "Only when we are culturally secure and autonomous and are confident in our varied heritage, in what we are, can we realize our full potential for sharing what we have, our selves, with others. We can create and subscribe to common cultural values while maintaining our differences" (Hau'ofa I993b, I32). 
Hau'ofa has created a space that values Oceanic culture, knowledge, and styles, inspiring Irami Buli, Ben Fong, Mason Lee, Paula Liga, Josaia McNamara, Ledua Peni, Josua Toganivalu, Lingikoni Vaka'uta, and others to compose powerful visual narratives using styles resembling masi, re-presenting legends, or imaging responses to political strife that reflect and integrate their Oceanic experience. This validation of experience is a means of privileging indigenous epistemologies. David Welchman Gegeo and Karen Ann Watson-Gegeo discussed the value of engaging in local epistemology, which they defined as a "cultural group's ways of thinking and of creating, reformulating, and theorizing about knowledge via traditional discourses and media of communication, anchoring the truth of the discourse of culture.... As a concept, indigenous epistemology focuses on the process through which knowledge is constructed and validated by a cultural group, and the role of that process in shaping thinking and behavior" (Gegeo and Watson-Gegeo 200I, 58-59). These artists communicate through a process of creativity anchored in Oceanic ideals, which are thus relevant and accessible to their community.

The Oceania Centre affirms Oceanic identity through processes of exchange and creation within the wall-less structure. The integrated arts program draws from cultural heritage fusing traditions with contemporary; therefore it is appropriate that the space is also a fusion of modern architecture with traditional elements. Lingikoni points out that the center borrows Pacific concepts such as its open design, which is reminiscent of a Tongan or Samoan fale (open-sided structure built of local materials), yet constructed of concrete and metal. The space is adaptable as a communal structure should be; the veranda might host meetings, group lunches, or kava sessions (figure I 5), and the dance stage transforms into an art gallery. Josua and others draw inspiration from "creative energy flowing" in these adaptable spaces and "the sharing and learning" that goes on there. These are some of the prominent elements that contribute to the Oceania Centre's success, stemming from Oceanic life, practices, and architecture.

At the center, Oceanic artists look to tradition and history to speak of the present. As with any process, the creativity at the center is dynamic and not limited to contemporary or traditional. ${ }^{17}$ The art evolves. It invites the ancestors into conversations in the present to dream of the future (Epeli Hau'ofa, pers comm, 5 Jan 2007). It moves in whatever way the artist imagines it. For example, Irami refuses to be bound to a category such as Realist, Expressionist, or Abstract that boxes in his art. He trusts in his own identity and shares it through creative expressions. His art moves 


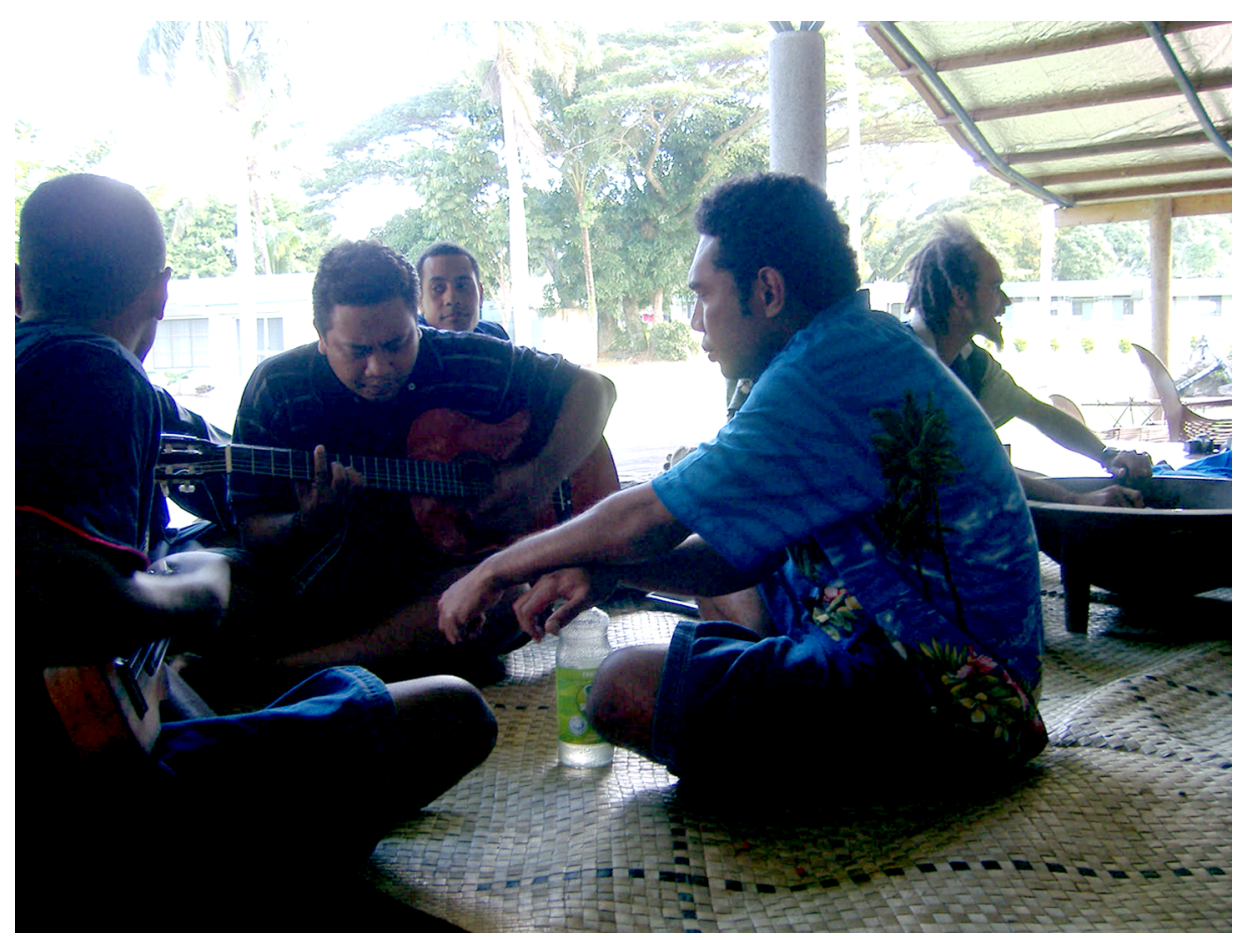

Figure I 5. Playing music during a kava session on Oceania Centre dance stage, 2006. Photo by author.

like the ocean's waves, changing with each tide, predictable only to those who pay close attention. I see this as one of the strongest assets to the integrated arts program.

The artists at the Oceania Centre are defining a new and autonomous category of art. They do not judge themselves in relation to European, Asian, or American artists. As Hau'ofa affirms in Beyond the Horizon, the Oceania Centre is carving out its own space in the global system that assesses itself according to Oceanic values rather than a foreign yardstick (Hau'ofa 2003a). There is an exciting unpredictability at the Oceania Centre that is akin to the ebb and flow of the tides.

Not every person who arrives at the center is an innate artist. Although there is a welcoming space for creativity, art is not everyone's forte. As Lingikoni Vaka'uta points out: "It's a hard life. . . . you have to really make a conscious decision to be an artist in the Pacific, in the islands, because the money doesn't really come in constantly."

The limited market for contemporary art in Suva exacerbates the need 
for passion because the life of an artist is rarely one of luxury. There is a limited clientele for this kind of high-quality contemporary art in Fiji. The center has been producing art for nearly a decade and patrons such as Hau'ofa will soon run out of space in their homes. However, the ability to make a career from expressing creativity is a privilege embraced and recognized by the artists at the center.

Given the numerous limitations and challenges I have cited, what is the future of this dynamic space for the arts? The center has expanded and absorbed nearly all of the space designated for it at the back of the UsP campus. Perhaps, as Lingikoni says, the artists will simply continue to improvise, making the most of the space available. The concomitant benefits of their association with and marginalization by academia are a blessing in that the artists are free to experiment; if they were not being nurtured and supported by the center, they might succumb to market pressures and commercialization. The artist's freedom to create is integral to the processes and unique imagery emerging. The exquisite variety of imagery and form might not exist if artists had had to cater to the art market. This is not to say that the artists are not acutely aware of the local and international art markets and the clientele that patronize those markets; after all, their work has been exhibited and sold in numerous countries, extending from Oceania to Europe.

International exhibitions and visiting artists from Aotearoa/New Zealand, Solomon Islands, Tonga, and Vanuatu have created exchanges that benefit the artists. These exchanges also challenge and advance the artists' visibility. Does advancing entail one day leaving the center to become professionals? Each of the artists I have referred to in this paper negotiates a careful balance between individual career and his role as part of the Oceania Centre. They have solo exhibitions that contribute to the cooperative community of the center. Though there is a communal spirit of shared learning, there is also opportunity and encouragement for success, whether through individual advancement and assertion or overall success as a collective.

The Oceania Centre has been quietly thriving for over a decade. During this time, Hau'ofa has imagined and nurtured an unprecedented space for creativity the likes of which has never before been seen in Oceania. His reward is the emergence of a unique style of contemporary art that is attracting international attention. Most importantly, this art remains relevant to and reflective of the community that it serves. 
My SINCERE THANKs Go TO Epeli Hau'ofa, the artists, and the staff at the Oceania Centre for welcoming me as a visiting artist; their creativity, generosity, and insight continue to inspire me. The University of Hawai' $i$ Center for Pacific Islands Studies provided me with crucial encouragement during both of my residencies to the Oceania Centre, for which I am indebted. I am grateful to Barbara Hau'ofa for her comments on an earlier draft of this paper as well as those by anonymous reviewers. Finally, many thanks to Vilsoni Hereniko and Jan Rensel for giving me the opportunity and support to share this story that I am so passionate about. Any inaccuracies written here are entirely my responsibility.

\section{Notes}

I USP member countries are Cook Islands, Fiji, Kiribati, Marshall Islands, Nauru, Niue, Sāmoa, Solomon Islands, Tokelau, Tonga, Tuvalu, and Vanuatu.

2 All of the Red Wave artists that I introduce in this project are male. Although there have been and are female participants, there is an obvious gender disproportion in terms of painters and sculptors. The issue of gender at the Oceania Centre is one that I do not develop here because my intention is to introduce some of the artists and their art rather than critique the composition of the center's programs.

3 Terry D Webb noted that the Polynesian Cultural Center (PCC) has drawn criticism because of its superficial presentation of the Pacific as tourist art. "[I]t is preserving popular notions of Polynesia, because the PCC is a business, its claims of cultural preservation notwithstanding. . . . [Further, it] is an example of how tourist art can be endowed with more than economic values, and it has much to teach about the complex function of tourist art in a developing society" (I994, $80-8 \mathrm{I})$.

4 This report is cited in a 2003 lecture by Epeli Hau'ofa titled, "Our Place Within: Foundations for a Creative Oceania," which, unfortunately, is not yet available at the UsP or UH library.

5 Georgina Beier wrote a report on the viability of an alternative arts program in Papua New Guinea based on apprenticeships with traditional artists and workshops at an arts center (1974). She anticipated that the advantages of this program would be:

I. it gives the artist a thorough grounding in his own artistic tradition before exposing him to other cultures. 2. the emphasis is firmly placed on practical rather than theoretical studies. 3 . it concentrates on techniques that could easily be carried out in most parts of Papua New Guinea. 4. it replaces the classroom atmosphere with a workshop atmosphere. 5 . it tries to incorporate the 
virtues of the traditional apprenticeship system, while at the same time giving the student the varied techniques and the wider outlook that are required in the world today. 6 . the scheme is tough on the students and success depends entirely on the student's own initiative and imagination.... Thus the scheme might reintroduce the kind of natural selection process that has always operated on the village level, but which is being fuzzed over in the modern art school. (Beier 1974, I2)

These elements are apparent in the Oceania Centre.

6 'Atenisi Institute in Tonga is named for the Greek capital, Athens. The institute is independent of both church and state. The educational focus is on classical and theoretical curriculum inspired by the Greeks, founded in classical languages, philosophy, art, and literature ('Atenisi Institute Web site).

7 Elise Huffer and Ropate Qalo wrote: "Constructing a body of thought, much like building a Samoan fale (house), has significance in itself, but it must first and foremost be of use to the community it is designed for. . . . In short, a body of Pacific thought should contribute to the establishment or affirmation of a Pacific philosophy and ethic-a set of applicable concepts and values to guide interaction within countries, within the region, and with the rest of the world" $(2004,89)$. Therefore we can associate the style of the structure with the processes happening within.

8 The Red Wave artists have exhibited collectively as well as independently in places such as Australia, India, New Zealand, and the United Kingdom.

9 Lingikoni Vaka'uta explained the meaning of Red Wave during an interview.

Io For a more detailed history of the Oceania dance program, see Hereniko 2006.

I I All of the conversations quoted are from transcribed video footage taken during July 2006 at the Oceania Centre for Arts and Culture. The interviews were conducted for the purpose of producing a project based on the artistic space of the center and are reproduced with permission from the artists.

I 2 "Fiji, the way the world should be!" was the famous slogan used by Fiji's tourism industry during the late seventies and early eighties (Hereniko 2003, $82)$.

I3 Ben was suggesting that people do not realize that he is indigenous Fijian as well as Chinese.

I4 The Red Wave Collective exhibited at London's October Gallery in May 2006. Toganivalu was also referring to a panel at the Indigenous Epistemology Conference that took place just a week before this interview, in July 2006, which acknowledged the vibrant expressions and innovative arts happening at the Oceania Centre. 
I 5 Rather than using their cultural knowledge and experience, the artists draw from it. James Clifford critiqued the imposed meanings associated with culture and art: "Art collecting and culture collecting now take place within a changing field of counterdiscourses, syncretisms, and reappropriations originating both outside of and inside 'the West.' . . . 'Culture' and 'art' can no longer be simply extended to non-Western peoples and things. They can at worst be imposed, at best translated-both historically and politically contingent operations" (I990, I 55 ; emphasis in original).

I6 Discussing creativity in the Pacific, Susan Cochrane wrote: "Some of this artistic code is inherited, some of it learnt, some of it comes from experience and experimentation. But when the code is found it gives form to a vision and expression which can be shared with others" (200I, 43).

I7 Nicholas Thomas discussed the limitations of the terms: “Traditional' and 'contemporary' seem, however, to have become words that we are stuck with. The dichotomy remains a problem, not because all dichotomies are necessarily bad, but because it suggests a linear progression from the traditional to the contemporary. . . . 'Contemporary' could simply mean 'of the present', but often means 'of the international art world'” (I996, I7). Philip J C Dark also wrote: "Many traditional arts persist though changed; others are reconstructions; others are traditional forms adapted and used to make new ones" (I999, 268). And as Karen Stevenson put it in a catalog for an exhibition of Pacific art in New York: "Creating a cultural foundation supported by a traditional past and invigorated by the present, the island and the urban have come together in the creation of a spirited Pacific art movement" (Asia Society 2004, 22).

\section{References}

Asia Society

2004 Paradise Now? Contemporary Art from the Pacific. Exhibition catalog. Albany, NY: Asia Society; Auckland: David Bateman Ltd.

'Atenisi Institute Web site. http://www.atenisi.edu.to [accessed 26 November 2006]

Beier, Georgina

I974 A Papuan New Guinean Alternative to a Degree Course in Fine Art. Discussion Paper 2. Port Moresby: Institute of Papua New Guinea Studies.

Clifford, James

I990 On Collecting Art and Culture. In Out There: Marginalization and Contemporary Cultures, edited by Russell Ferguson, Martha Gever, Trinh T Minh-Ha, and Cornel West, I4I-I69. New York: The New Museum of Contemporary Art; Cambridge, mA: мIт Press. 
Cochrane, Susan

I995 Art in the Contemporary Pacific. Art and AsiaPacific 2 (4): 50-59.

200I Bérétara: Contemporary Pacific Art. Sydney, Nsw: Halstead Press.

Dark, Philip J C

I999 Of Old Models and New in Pacific Art: Real or Spurious? In Art and Performance in Oceania, edited by Barry Craig, Bernie Kernot, and Christopher Anderson, 266-288. Honolulu: University of Hawai'i Press.

Gegeo, David Welchman, and Karen Ann Watson-Gegeo

200 I “How We Know": Kwara'ae Rural Villagers Doing Indigenous Epistemology. The Contemporary Pacific I 3:5 5-88.

Hau'ofa, Epeli

I993a Our Sea of Islands. In A New Oceania: Rediscovering Our Sea of Islands, edited by Eric Waddell, Vijay Naidu, and Epeli Hau'ofa, 2-I8. Suva: University of the South Pacific. Reprinted in The Contemporary Pacific 6:I47-I6I (I994).

I993b A Beginning. In A New Oceania: Rediscovering Our Sea of Islands, edited by Eric Waddell, Vijay Naidu, and Epeli Hau'ofa, I26-I39. Suva: University of the South Pacific.

200I Oceania Centre for Arts and Culture Corporate Plan. Suva: University of the South Pacific.

2003a Beyond the Horizon: Creative Expression in Contemporary Oceania. vHs, color, 53 minutes. Presentation by Epeli Hau'ofa. Honolulu: East-West Center and Center for Pacific Islands Studies, University of Hawai'i at Mānoa.

2003 b Our Place Within: Foundations for a Creative Oceania. The 2003 Forge Memorial Lecture, The Australian National University, Canberra, 8 October. Copy in author's files.

Hereniko, Vilsoni

I999 Representations of Cultural Identity. In Inside Out: Literature, Cultural Politics, and Identity in the New Pacific, edited by Vilsoni Hereniko and Rob Wilson, I37-I66. Lanham, MD: Rowman \& Littlefield.

2003 Interdisciplinary Approaches in Pacific Studies: Understanding the Fiji Coup of I9 May 2000. The Contemporary Pacific 1 5:75-90.

2006 Dancing Oceania. In The Fifth Asia-Pacific Triennial of Contemporary Art, edited by Lynne Seear and Suhanya Raffel, 32-4I. Brisbane, QLD: Queensland Art Gallery.

Huffer, Elise, and Ropate Qalo

2004 Have We Been Thinking Upside-Down? The Contemporary Emergence of Pacific Theoretic Thought. The Contemporary Pacific I6:87-I I6. 
Thomas, Nicholas

I996 Contemporary Art and the Limits of Globalisation. In The Second AsiaPacific Triennial of Contemporary Art, I7-I 8. Brisbane, QLD: Queensland Art Gallery.

Webb, Terry D

I994 Highly Structured Tourist Art: Form and Meaning of the Polynesian Cultural Center. The Contemporary Pacific 6:59-86.

\section{Abstract}

The Oceania Centre for Arts and Culture at the University of the South Pacific in Suva, Fiji, is a space where Oceanic identity is expressed through painting, sculpture, music, and dance. For a decade, artists have been expressing a burgeoning Oceanic identity infused with traditions and histories expressed in the contemporary period through art. The founder and director, Epeli Hau'ofa, has nurtured a space for Oceanic arts that encourages a participative process of learning that speaks to the potential of each individual while simultaneously forming a dedicated community of artists learning from one another. What is unique about the Oceania Centre is the process of creation in which artists are forming and asserting their identity. This identity is respectful of and concerned with traditions, histories, current conditions (cultural, social, and political), and overall experience of Oceania. The process of participative creative exchange at the Oceania Centre is integrated throughout its painting, sculpture, dance, and music programs to produce expressions that move like waves with the fortitude and force of the ocean. As with any process, the creativity at the center is dynamic and not limited to the contemporary or traditional. The art evolves. It invites the ancestors into conversations in the present to dream of the future. Beginning with a brief history and introduction to Hau'ofa's vision, this article focuses on the Red Wave Collective, the group of painters and sculptors practicing at the Oceania Centre. These artists arrive at the Oceania Centre from different walks of life. Their qualification to join: experience of life as an Oceanian. Excerpts from interviews with some of the Red Wave painters and sculptors offer a glimpse into the value of participative learning space and the dynamic process of creativity at the Oceania Centre.

KEYWORDS: contemporary art, Oceanic art, Epeli Hau'ofa, Oceania Centre for Arts and Culture, Red Wave Collective 